Orientalia Christiana Cracoviensia 10 (2018), s. 47-109

DOI: http://dx.doi.org/10.15633/ochc.2977

Rafał Panfil

Muzeum Zamkowe w Malborku

\title{
Działalność misyjna jezuitów rezydencji malborskiej w świetle wykazu konwertytów z lat 1662-1679
}

\author{
Niniejszy tekst poświęcam pamięci dr. hab. Janusza Hochleitnera, \\ profesora Uniwersytetu Warmińsko-Mazurskiego w Olsztynie
}

\begin{abstract}
Missionary work of Malbork Jesuits in the light of converts coming from 1662-1679. After the end of the Second Northern War t Malbork Jesuits were performing their Christian ministry in the area of the desolated Pomesanian diocese. The work was launched in extreme living conditions. They started they work immediately after ceasing military actions. The missionaries, preachers and operators were setting off for parishes which were abandoned during the war by secular clergy in Żuławy Malborskie (Werder), Prusy Górne (Oberland) and the borderlands with Lutheran Dutchy of Prussia. One of the major tasks of the Malbork Jesuits was recatholisation of diocese areas which was carried out by missionary work and religious convertions of the local dissidents (mainly Lutherans) to Catholicism. Thanks to the report entitled Series eorum Qui Societatis Jesu opera ab Anno Salutis 1662 ad 1678, Fidem Catholicam sunt amplexi in Polonia we can learn about their missionary work. The report was originally prepared for Sacred Congregation for the Propagation of the Faith in Rome. The source text is the subject of the analysis in this article.

Działalność misyjna jezuitów rezydencji malborskiej w świetle wykazu konwertytów z lat 1662-1679. Po zakończeniu II wojny północnej (16561660) jezuici rezydencji malborskiej pełnili posługę duszpasterską na obszarze spustoszonej diecezji pomezańskiej. Pracę rozpoczęli niezwłocznie po zakończeniu działań wojennych w ekstremalnych warunkach bytowych. Misjonarze, kaznodzieje i operariusze wyruszali do opuszczonych przez duchowieństwo świeckie parafii na Żuławach Malborskich i w Prusach Górnych
\end{abstract}


oraz na pograniczu z luterańskimi Prusami Książęcymi. Jednym z głównych zadań jezuitów malborskich była rekatolizacja obszaru diecezji, której dokonywali poprzez pracę misyjną i konwersje na katolicyzm miejscowych innowierców, głównie luteran. Owoce pracy misyjnej jezuitów rezydencji malborskiej w latach 1662-1679 poznajemy dzięki tekstowi źródłowemu zatytułowanemu Series eorum Qui Societatis Jesu opera ab Anno Salutis 1662 ad 1678, Fidem Catholicam sunt amplexi in Polonia, który powstał w ramach sprawozdań Fructus Spiritualis przygotowywanych dla utworzonej w 1622 roku Kongregacji Propagandy Wiary w Rzymie. Jest on przedmiotem analizy w niniejszym artykule.

Keywords Jesuits, Malbork, Royal Prussia, missions, conversions to Catholicism

Jezuici, Malbork, Prusy Królewskie, misje, konwersje na katolicyzm

Tematyka konwersji z innych wyznań na katolicyzm w Malborku była dotychczas opracowana w bardzo ograniczonym zakresie. Biskup Julian Wojtkowski, który przetłumaczył na język polski kronikę jezuitów malborskich ${ }^{1}$, opublikował skromny przyczynek poruszający tematykę nawróceń w świetle tego źródła ${ }^{2}$. Zamieścił w nim tabelaryczne podsumowanie liczby innowierców nawróconych przez jezuitów malborskich w latach 1653-1743 na podstawie danych zaczerpniętych z kroniki ${ }^{3}$. O konwertytach malborskich wspomniał też Sławomir Kościelak w swoim opracowaniu na temat konwertytów elbląskich w XVIII wieku . Autor ten omówił wykorzystane w niniejszym artykule źródło, tj. listy konwertytów (Conversi) sporządzane przez poszczególne domy prowincji polskiej w latach 1662-16795. Wcześniej opracował również szeroko tematykę misji i konwersji prowadzonych przez jezuitów z kolegium w Starych Szkotach koło Gdańska, placówki nadrzędnej

1 Archiwum Archidiecezji Warmińskiej w Olsztynie, sygn. H. 11 (AAWO, H. 11), Historia Residentiae Mariaburgensis Ab Anno 1647. Fotokopia oryginału w zbiorach Działu Historii Muzeum Zamkowego w Malborku, sygn. mikrofilmu MZM/DW/80; Dzieje malborskiej rezydencji Towarzystwa Jezusowego 1647-1744. Z rękopisu H 11 Archiwum Archidiecezji Warmińskiej w Olsztynie przetożyt biskup Julian Wojtkowski, Olsztyn 2013.

2 J. Wojtkowski, Konwertyci w kronice jezuitów malborskich 1647-1744, w: Jezuici w Malborku a życie religijne na terytorium diecezji pomezańskiej w okresie nowożytnym, red. J. Hochleitner, Malbork 2014, s. 121-132.

3 J. Wojtkowski, Konwertyci w kronice jezuitów malborskich 1647-1744, dz. cyt., s. 123-124.

4 S. Kościelak, Konwertyci elbląscy w świetle jezuickiego Fructus missionis z XVIII wieku, „Rocznik Elbląski” 20 (2006), s. 183-192.

5 S. Kościelak, Konwertyci elblascy..., dz. cyt., s. 186. 
dla rezydencji malborskiej i najważniejszego ośrodka jezuickiego w Prusach Królewskich w Prowincji Polskiej Towarzystwa ${ }^{6}$.

Tekst zatytułowany Series eorum Qui Societatis Jesu opera ab Anno Salutis 1662 ad 1678, Fidem Catholicam sunt amplexi in Polonia powstał w ramach sprawozdań Fructus Spiritualis przygotowywanych dla utworzonej w 1622 roku Kongregacji Propagandy Wiary w Rzymie ${ }^{7}$. Stanowi dodatek do Historiae Poloniae 1648-1671. Sporządzono go później, niż sugerują daty końcowe w tytułach zarówno historii (1671) jak i samego wykazu (1678), ponieważ obejmuje wszystkie roczniki z lat 1662-16799. Całość przepisana została tą samą ręką i przesłana do Rzymu w marcu 1680 roku $^{10}$. Najpewniej uczynił to ówczesny historyk Prowincji Polskiej przy prowincjale ${ }^{11}$. Można przypuszczać, że większość wykazu malborskiego przygotował superior o. Piotr Brożycki (1635-1683), który w latach 1675-1677 pełnił w Malborku jednocześnie funkcję historyka rezydencji12. Pracę dokończył być może kolejny superior, o. Stanisław Młodkowski (1637-1711) lub prefekt szkół w latach 1679-1680 o. Ignacy Studnicki (1648-1718)13. Tekst źródłowy zawiera wykazy konwersji dokonanych przez poszczególne domy zakonne (22) w Prowincji Polskiej Towarzystwa Jezusowego w latach 1662-1679². Wykazy

6 S. Kościelak, Jezuici w Gdańsku od drugiej połowy XVI do końca XVIII wieku, Gdańsk-Kraków 2003.

7 S. Kościelak, Konwertyci elbląscy..., dz. cyt., s. 184.

8 Archivum Romanum Societatis Iesu (ARSI), Historiae Poloniae 1648-1671, Pol. 53, Series eorum Qui Societatis Jesu opera ab Anno Salutis 1662 ad 1678, Fidem Catholicam sunt amplexi in Polonia [dalej: Series eorum], Mariaeburgensis Residentia, k. 252-268v. W górnym prawym rogu każdej karty znajduje się dodatkowa numeracja stron od 1 do 43 . Wykaz konwertytów malborskich zamieszczono na kartach 262v.-268v. (s. 22-34).

9 Do końca roku sprawozdawczego 1678/1679, którymi posługiwali się jezuici w swojej rachubie czasu opartej na cyklu lat szkolnych. W tym przypadku wykaz kończy się w czerwcu 1679 roku, kiedy to przypadał koniec roku szkolnego 1678/1679.

10 Świadczy o tym adnotacja na ostatniej karcie (k. 273v., s. 44 spisu): 1680 Polonia Numerus Convertorum ad fidem ab anno 1662 ad 1678. 30 Marti. Data końcowa jest ponownie nieprecyzyjna, ponieważ np. ostatni konwertyta malborski wspomniany został pod datą 4 czerwca 1679 roku.

11 Hasło: Litterae Annuae, w: Encyklopedia wiedzy o jezuitach na ziemiach Polski i Litwy 15641995 (EWJ), oprac. L. Grzebień SJ przy współpracy zespołu jezuitów, wyd. 2, Kraków 2004, s. 368 ,

12 ARSI, Pol. 44, Catalogus Brevis Provinciae Poloniae 1674/1675 [dalej: Cat. Brev.], k. 263v.; ARSI, Pol. 16, Catalogus Triennalis 1675 [dalej: Cat. Trienn.], k. 35; Cat. Brev. 1675/1676, k. 284v.; Cat. Brev. 1676/1677, k. 295v.

13 Cat. Brevis 1679/1680, k. 311.

14 Kolegia w Barze na Podolu, Bydgoszczy, Brześciu Litewskim, Kaliszu, Krakowie (kolegium i Dom Probacji), Krośnie, Gdańsku, Grudziądzu, Jarosławiu (2 kolegia), Lwowie, Lublinie, 
konwertytów w większości przypadków są niekompletne, obejmując tylko niektóre roczniki we wskazanym okresie 17 lat. Listy osób nawróconych przez jezuitów rezydencji malborskiej są kompletne w takim sensie, że obejmują wszystkie lata zawarte we wskazanym powyżej przedziale czasowym, w przeciwieństwie do wykazów pochodzących z niektórych innych placówek Prowincji Polskiej. Np. kolegium w Grudziądzu nie przygotowało takich list wcale ${ }^{15}$. Z innych źródeł proweniencji jezuickiej, takich jak kroniki (Historiae), annały (Annuae) czy niektóre katalogi trzyletnie (Catalogus Triennalis) wiadomo jednak, że jezuici grudziądzcy prowadzili działalność misyjną w ograniczonym zakresie ${ }^{16}$.

Z drugiej strony nie można uznać wykazu konwertytów malborskich za zupełnie kompletny z powodu istniejących w nim najpewniej luk. Listy konwertytów dla niektórych lat obejmują tylko część roku szkolnego, jak np. wykaz za rok 1662 kończy się w ostatnich dniach września, a kolejny rok 1663 zaczyna się na początku sierpnia ${ }^{17}$. Brak zatem wykazu osób nawróconych w roku szkolnym 1662/1663 r. Podobnie rok 1667 kończy się na czerwcu, a kolejny rok 1668 zaczyna od września ${ }^{18}$. Wreszcie finalny rocznik doprowadzony został tylko do czerwca 1679 czyli końca roku szkolnego 1678/1679, ale połowy roku kalendarzowego. Innym dowodem wskazującym na niekompletność spisu są krótkie komentarze umieszczone w podsumowaniu roczników 1664, 1665, 1667, 1668, 1669 i 1670 mówiące o innych osobach nawróconych, których imion nie zapisano. Jednakże w porównaniu z innymi równoległymi sprawozdaniami jezuickimi, Series eorum jest źródłem o wyjątkowej wartości poznawczej, które daje nam najgłębszy możliwy wgląd w tożsamość konwertytów z lat 60. i 70. XVII wieku.

Nawet pobieżna analiza językowa pokazuje, że tekst Series eorum pisany był przez Polaka. Dowód stanowią liczne polonizmy, czyli prawidłowy

Łucku, Ostrogu, Poznaniu, Przemyślu, Rawie i Toruniu oraz rezydencje w Chojnicach, Malborku i Wałczu.

15 Podano jedynie liczbę osób nawróconych w latach 1662-1678: 60 luteran, 1 mennonita i 1 prawosławny - Series eorum, k. 258v.

16 Ponieważ placówka grudziądzka miała wówczas status kolegium w stanie początkowym i nieliczną w stosunku do innych kolegiów obsadę, pracujący tam jezuici zajmowali się głównie nauczaniem.

17 Series eorum, k. 262v. -263.

18 Stąd zapewne pod koniec listy konwertytów za 1667 rok zdanie: „Plures Sunt S[ancti] Matri Ecclesiae aggregati non annotati” - Series eorum, k. 265, por. Załąznik źródtowy. Potwierdzają to także dane z Historia Residentiae Mariaburgensis, gdzie podano, że w roku 1666/1667 było 40 nawróceń w przeciwieństwie do „ponad” 25 wymienionych w Series eorum. 
zapis polskich nazw miejscowych, osobowych i innego słownictwa, które pomimo umieszczenia $\mathrm{w}$ tekście łacińskim albo nie zostały zlatynizowane, albo nie podano ich w wersji niemieckiej, co byłoby zrozumiałe ze względu na specyfikę obszaru działań rezydencji malborskiej. Są to np.:

- antroponimy: Dorothea Ratkówna ${ }^{19}$, Sara Balińska ${ }^{20}$, Anna Kulpierzowa ${ }^{21}$, Domina Chodzewska ${ }^{22}$ itd.,

- toponimy: Jacobus de Pawłowo ${ }^{23}$, Prabuto ${ }^{24}$, Villa Węgry ${ }^{25}$, Peter Werner Colonus in Fiszewie ${ }^{26}$, Elisabeth z Rakowca ${ }^{27}$, Gertrudis Petersche z Heybud ${ }^{28}$, Barbara Filia Weisz z Piasku², Joannes Sartor Brądewaldensis $^{30}$

- inne słownictwo: sierżant ${ }^{31}$, Barbara Anna Brettersche Porucznikowa ${ }^{32}$, Hans Senka woźny ${ }^{33}$, Jurek Parobek ${ }^{34}$, Fridericus Fittloff Laux porucznik $^{35}$, Catharina Frezerin kapitanowa ${ }^{36}$, Regina kapralowa ${ }^{37}$, Laboriosus Sulaviensis oraz Jacobus Colonus Żulaviensis ${ }^{38}$.

Przedstawiony w załączniku do niniejszego artykułu wykaz konwertytów malborskich pochodzi z cyfrowej kopii oryginału przechowywanej w Bibliotece Akademii Ignatianum w Krakowie.

19 Series eorum, k. $262 \mathrm{v}$.

20 Series eorum, k. 262v.

21 Series eorum, k. 263v.

22 Series eorum, k. 268.

23 Series eorum, k. 263.

24 Miasto Prabuty, niem. Riesenburg, ówczesnie na terenie niemieckojęzycznych Prus Książęcych Series eorum, k. 262v.

25 Niem. Brunswalde, późn. Braunswald - Series eorum, k. 262v.

26 Zamiast: in Fischewo lub Fischau - Series eorum, k. 264.

27 Zamiast: de Rakowiec - Series eorum, k. 264.

28 Zmiast: de Heybuden - Series eorum, k. 264.

29 Zamiast: de Piaski-Series eorum, k. 264.

30 Series eorum, k. 268.

31 Series eorum, k. 263v.

32 Series eorum, k. 264.

33 Series eorum, k. 264v.

34 Series eorum, k. 265v.

35 Series eorum, k. 266v.

36 Series eorum, k. 266v.

37 Series eorum, k. 266v.

38 Zamiast: de Insula - Series eorum, k. 266v.-267. 


\section{Misje w rezydencji malborskiej jezuitów po 1660 roku}

Placówka jezuicka w Malborku powstała 6 stycznia 1618 roku jako misja podległa rezydencji gdańskiej ${ }^{39}$. Podstawowym celem malborskich jezuitów była rekatolizacja miejscowych innowierców (głównie luteran) ${ }^{40}$ poprzez prowadzenie działalności duszpasterskiej na terenie miasta, przedmieść, zamku, na obszarze ekonomii malborskiej (królewszczyzny obejmującej Wielkie i Małe Żuławy Malborskie) oraz w pozostałych częściach diecezji pomezańskiej, jak również w przygranicznych obszarach Prus Książęcych. Działalność duszpasterska, czyli niesienie pomocy bliźnim ${ }^{41}$, polegała na odprawianiu nabożeństw, udzielaniu sakramentów spowiedzi, komunii świętej, chrztu świętego, małżeństwa, wygłaszaniu kazań rekolekcyjnych w języku polskim i niemieckim, nauczaniu katechizmu, niesieniu posługi chorym, umierającym, skazańcom, więźniom, ubogim i ludziom z marginesu społecznego, rozjemstwie w sprawach spornych, umacnianiu w wierze katolików (szczególnie na terenie Prus Książęcych), legalizacji nieformalnych związków małżeńskich itp. ${ }^{42}$.

Podczas II wojny szwedzkiej z lat 1655-1660 miejscowi katolicy w Prusach Królewskich stali się ofiarami prześladowań ${ }^{43}$. W efekcie duchowieństwo diecezji pomezańskiej poniosło niepowetowane straty personalne i materialne ${ }^{44}$. To samo dotyczyło ludności świeckiej. Ówczesny opłakany stan, w jakim znajdował się po wyjściu Szwedów zamek, przedmieścia Malborka, obszar ekonomii malborskiej, jak i samo miasto, odzwierciedlają źródła proweniencji pozajezuickiej. Z kontraktów zawartych przez króla Jana Kazimierza w latach 1660 i 1663 z nowymi arendarzami ekonomii oraz

39 Cat. Brev. 1617/1618, k. 124v.; Cat. Brev. 1618/1619, k. 126v.; Cat. Brev. 1619/1620, k. 140; S. Kościelak, Jezuici w Gdańsku..., dz. cyt., s. 250; S. Kościelak, Jezuici w trzech wielkich miastach pruskich w XVI-XVIII w., „Hereditas Monasteriorum” 3 (2013), s. 170; ADP, C. 3, k. 106v.-112. Szerzej na ten temat zob.: R. Panfil, Stosunki religijne w Malborku od poczatku reformacji do poczatku XVII w., „Studia Zamkowe” 5 (2018), s. 93-108.

40 J. Łukaszewska-Haberkowa, Wpływ pierwszego pokolenia polskich jezuitów na życie kulturalne i religijne Rzeczypospolitej Obojga Narodów w latach 1564-1608, Kraków 2014, s. 89.

41 Również „pomoc duszom”, ,posługa wiary” - Konstytucje TJ, s. 225-228; J. Kołacz, Słownik języka i kultury jezuitów polskich, dz. cyt., s. 203-204.

42 AAWO, H. 11, Historia Residentiae Mariaburgensis, k. 12v.-22v.; Konstytucje TJ, s. 225-228.

43 Szerzej: M. Józefczyk, Z dziejów religijnych Pomezanii w XVII wieku, t. 1, Synteza dziejów, Malbork 2012, s. 83.

44 S. Kościelak, Dzieje wyznaniowe Prus Królewskich w XVI-XVIII w., w: Prusy Królewskie spoteczeństwo, kultura, gospodarka 1454 - 1772. Szkice z dziejów, red. E. Kizik, Gdańsk 2012, s. 237; R. Panfil, Starania Stanistawa Kuklińskiego o przejęcie kościoła zamkowego w Malborku, „Echa Przeszłości” nr 18 (2017), s. s. 174. 
z akt komisji królewskiej z 1661 roku wyłania się ponury obraz całkowitej ruiny gospodarczej ${ }^{45}$.

Powojenne realia spowodowały, że jezuici musieli objąć zatępczo obowiązki nielicznego i opieszale wracającego do swoich parafii kleru świeckiego $^{46}$. Już 21 maja 1660 roku dwóch jezuitów, o. Walenty Sophronius (1600-1667) i b. Jan Ceparius (1604-1670), powróciło do Malborka ${ }^{47}$. Na miejscu zastali ruiny rezydencji oraz zrównaną z ziemią kaplicę nadbramną Najświętszej Marii Panny ${ }^{48}$, o którą tak pilnie zabiegali przed wojną ${ }^{49}$. Świątynia ta miała dla jezuitów malborskich szczególne znaczenie z powodu tak charakterystycznej dla ich zakonu religijności maryjnej. Od początku pobytu w Malborku jezuici specjalną opieką otaczali znajdujący się w tejże kaplicy cudowny obraz Matki Boskiej z Dzieciątkiem ${ }^{50}$.

Aż do września 1660 roku byli w stanie utrzymać się jedynie dzięki pomocy miejscowych katolików ${ }^{51}$. W drugiej połowie roku rezydencja liczyła

45 Zob.: Źródla do dziejów ekonomii malborskiej, t. 4, Akta malborskiej komisyjej za konstytucyja roku 1661 odprawionej i na dalszy czas odtożonej, wyd. W. Hejnosz, J. Waluszewska, Toruń 1967, s. 3; Archiwum Główne Akt Dawnych, Metryka Koronna, Kontrakt o Malborską Ekonomię 1660, Lustracje, dz. XVIII, sygn. 78, s. 168; R. Panfil, Kontrakt na ekonomię malborska z 1663 r., w: W slużbie zabytków. Księga Pamiątkowa ofiarowana Mariuszowi Mierzwińskiemu w 40-lecie pracy muzealnej w Malborku, red. J. Hochleitner, K. Polejowski, Malbork 2017, s. 191.

46 Podobnie było np. w Nieświeżu, o czym niedawno pisał A. Mariani, Duszpasterstwo jezuitów nieświeskich w XVII-XVIII wieku. Między ideatem potrydenckim a lokalnymi uwarunkowaniami, „Rocznik Lituanistyczny” 2 (2016), s. 58.

47 Obaj pracowali w rezydencji malborskiej przed wybuchem wojny w 1656 roku.

48 Zob. W. Długokęcki, Kaplica i wikaria Najświętszej Marii Panny na Bramie Przewozowej w Malborku w średniowieczu, w: Mieszczanie, wasale, zakonnicy, red. B. Śliwiński, Gdańsk 2004, s. 61-73 (Studia z Dziejów Średniowiecza, 10); S. Kościelak, Jezuici w Gdańsku..., dz. cyt., s. 190-192; S. Kościelak, Dzieje wyznaniowe Prus Królewskich w XVI-XVII w., dz. cyt., s. 233.

49 Conciliata armis et conditionibus pace cum Suecis quorum armato praesidio Mariaeburgen una cum arce per triennium tenebatur vigesima prima Maii duo e nostris ad ruinas Residentia rediere [...] itp.-ARSI, Pol. 53, Annuae Provinciae Poloniae Anni 1660, Mariaeburgensis Residentia, k. $105 \mathrm{v} .-106$.

50 A. S. Labuda, Zaginione, nieodnalezione. O obrazie Matki Boskiej Pokornej z Malborka oraz o predelli oltarza św. św. Piotra i Pawła z kościoła Mariackiego w Gdańsku, w: Żeby wiedzieć. Studia dedykowane Helenie Makiewiczównie, red. W. Walanus, Kraków 2008, s. 8198; ARSI, Pol. 52, Annuae Residentiae Mariaeburgensis Annorum 1642, 1643, 1644, k. 327327v.; ARSI, Pol. 52, Annuae Literae Provinciae Polonae Societatis Jesu Anni 1638, Residentia Mariaeburgensis, k. 147v.

51 W kronice błednie opisano te wydarzenia pod rokiem 1661 -AAWO, H. 11, Historia Residentiae Mariaburgensis, k. 12v. 
już jednak 3 ojców i 1 brata ${ }^{52}$. Żywność na potrzeby domu, uzyskaną w ramach wyżebranej jałmużny, jeden z ojców przez kolejne 1,5 roku przywoził aż z Człuchowa ${ }^{53}$.

Podjęta działalność kaznodziejska polegała na wygłaszaniu dwóch kazań (przed południem i po południu) w języku polskim w kościele parafialnym w każdą niedzielę i uroczyste święta. Do pomocy w parafii jezuici malborscy zobowiązani byli przywilejem Jana Kazimierza z 1652 roku, nadającym im kościół zamkowy Najświętszej Marii Panny ${ }^{54}$. Ponieważ świątynia ta została sprofanowana i podobnie jak cały zamek znajdowała się w opłakanym stanie technicznym, w jej wnętrzu nie można było prowadzić działalności duszpasterskiej. Po przybyciu we wrześniu kaznodziei niemieckiego Jana Peceldusa (1626-1684) wygłaszano również kazania po niemiecku ${ }^{55}$. Bardzo szybko zaangażowano się w działalność misyjną.

Ponieważ Series eorum rozpoczyna się dopiero w 1662 roku, informacje o wcześniej odbytych misjach znajdujemy w innych źródłach, mianowicie w kronice rezydencji malborskiej oraz rocznikach. Według tego ostatniego źródła do grudnia 1660 roku miano nawrócić 15 ,heretyków” i 2 ,schizmatyków”56, a w roku kolejnym 14 luteran i jednego „schizmatyka"57. Jednakże roczniki oraz kronika rezydencji informują bardzo ogólnie o miejscach i terminach, w których wychodzono na misje ${ }^{58}$. Odbywały się one głównie w niedziele i święta nakazane na miejscu w Malborku, na Żuławach Malborskich, w opustoszałych po wojnie parafiach w Prusach Górnych ${ }^{59}$ oraz na terytorium

52 Byli to ojcowie: superior Walenty Sophronius, Jan Gasparides, Jan Peceldus oraz brat Jan Ceparius - Cat. Brev. 1660/1661, k. 174v.

53 AAWO, H. 11, Historia Residentiae Mariaburgensis, k. 13. Odległość między Malborkiem a Człuchowem wynosi $125 \mathrm{~km}$. Podróż wymagała przeprawy przez dwie duże rzeki (Nogat i Wisłę) oraz podtopione wówczas Żuławy.

54 R. Panfil, Starania Stanistawa Kuklińskiego ..., dz. cyt., s. 194.

55 AAWO, H. 11, Historia Residentiae Mariaburgensis, k. 13.

56 ARSI, Pol. 53, Annuae Provinciae Poloniae Anni 1660, Mariaeburgensis Residentia, k. 105v.106.

57 ARSI, Pol. 53, Annuae Provinciae Poloniae Anni 1661, Residentia Mariaeburgensis, k. 121.

58 Właściwie tylko raz, kiedy jest mowa o opuszczonym kościele w Tychnowach (1665), w którym jezuici malborscy odprawiali nabożeństwa i spowiadali- AAWO, H. 11, Historia Residentiae Mariaburgensis, k. 14v.; Zob. np. ARSI, Pol. 53, Annuae Provinciae Polonae 1666, Mariaeburgensis Residentia, k. 179 - Missiones singulis Dominicis et festis diebus exercuit in Parochiis desertis, et Ecclesiis montanae Prussiae; również ARSI, Pol. 53, Annuae Provinciae Polonae 1669, Mariaeburgensis Residentia, k. 196v.-197 itp.

59 Tutaj w dosłownym tłumaczeniu: „wyżynne rejony Prus”. Zob: Oberland, w: Słownik geograficzny Królestwa Polskiego i innych krajów stowiańskich, t. 7, Warszawa 1886, s. 322. 
Prus Książęcych ${ }^{60}$. Niestety na podstawie tych źródeł nie da się dla badanego okresu ustalić pełnej liczby odbywanych rocznie misji. W roku 1672 było ich 18, w 1683 roku 19, także 19 w roku 1684, a w latach 1690-1692 łącznie 50 (średnio około 17 rocznie) ${ }^{61}$. Należy zatem zadać pytanie, czy Series eorum pozwala na uzyskanie pełniejszego obrazu?

Tab. 1. Liczba misji rezydencji malborskiej w latach 1662-1679 na podstawie Series eorum.

\begin{tabular}{|c|c|c|}
\hline Rok & Miejscowości, do których wychodzono na misje & $\begin{array}{l}\text { liczba } \\
\text { odbytych } \\
\text { misji }\end{array}$ \\
\hline 1662 & $\begin{array}{c}\text { Malbork (przedmieścia i podzamcze), Nowy Staw (miasto, Wielkie Żuławy } \\
\text { Malborskie), Kaczynos (Małe Żuławy Malborskie), Jasna, Pietrzwałd, } \\
\text { Mątki, Dzierzgoń (miasto), Prusy Książęce }\end{array}$ & 9 \\
\hline 1663 & $\begin{array}{c}\text { Malbork, Węgry (wieś między Malborkiem a Sztumem), } \\
\text { Prabuty (miasto, Prusy Książęce) }\end{array}$ & 3 \\
\hline 1664 & $\begin{array}{l}\text { Malbork (podzamcze i przedmieścia), Lichnowy } \\
\text { (Wielkie Żuławy Malborskie), Prusy Górne, Prusy Książęce }\end{array}$ & 5 \\
\hline 1665 & $\begin{array}{c}\text { Malbork (podzamcze i przedmieścia), Bystrzec, Tychnowy, Prusy Górne, } \\
\text { Prusy Książęce }\end{array}$ & 6 \\
\hline 1666 & $\begin{array}{c}\text { Malbork (zamek, podzamcze, miasto), Piaski (folwark zamkowy), } \\
\text { Nowa Wieś Malborska, Dąbrowa (Wielkie Żuławy Malborskie), } \\
\text { Stogi Malborskie (Wielkie Żuławy Malborskie), Fiszewo (Żuławy Elbląskie), } \\
\text { Mątowy Wielkie, Prusy Książęce, Rakowiec k. Kwidzyna (Prusy Książęce) }\end{array}$ & 11 \\
\hline 1667 & $\begin{array}{c}\text { Malbork (miasto, przedmieścia), Nowa Wieś Malborska, Kamionka (folwark } \\
\text { zamkowy, Wielkie Żuławy Malborskie), Stogi Malborskie (Wielkie Żuławy } \\
\text { Malborskie), Lichnowy (Wielkie Żuławy Malborskie), Prusy Książęce }\end{array}$ & 7 \\
\hline 1668 & Malbork (miasto), Sztum (miasto), Dzierzgoń (miasto), Prusy Książęce & 4 \\
\hline 1669 & $\begin{array}{c}\text { Malbork (podzamcze), Żuławy, Fiszewo (Żuławy Elbląskie), Prusy Górne, } \\
\text { Prusy Książęce }\end{array}$ & 5 \\
\hline 1670 & $\begin{array}{c}\text { Malbork (miasto, przedmieścia), Wielbark (obecnie Malbork-Wielbark), } \\
\text { Nowy Staw (miasto, Wielkie Żuławy Malborskie), Prusy Górne, } \\
\text { Prusy Książęce }\end{array}$ & 6 \\
\hline 1671 & Malbork (miasto, przedmieścia), Prusy Książęce & 3 \\
\hline
\end{tabular}

60 ARSI, Pol. 53, Annuae Provinciae Poloniae 1664, Residentia Mariaeburgensis, k. 145-145v.; ARSI, Pol. 53, Annuae Provinciae Polonae 1665, Mariaeburgensis Residentia, k. 151v.-152; ARSI, Pol. 53, Annuae Provinciae Polonae 1665, Mariaeburgensis Residentia, k. 152; ARSI, Pol. 53, Annuae Provinciae Polonae 1666, Mariaeburgensis Residentia, k. 179.

61 ARSI, Pol. 54, Annuae Provinciae Polonae 1672, Mariaeburgensis Residentia, k. 94; Historiae Residentiae, k. 25v.; ARSI, Pol. 55, Historia Triennalis Residentiae Mariaeburgensis Societatis Jesu Annus 1683, k. 159v.; Missiones ut supra - ARSI, Pol. 55, Historia Triennalis Residentiae Mariaeburgensis Societatis Jesu Annus 1684, k. 160; ARSI, Pol. 61, Annuae Poloniae 1685-1710, k. 78. 


\begin{tabular}{|c|c|c|}
\hline 1672 & $\begin{array}{l}\text { Malbork (miasto, przedmieścia, podzamcze), Stara Kościelnica } \\
\text { (Wielkie Żuławy Malborskie), Żuławy, Prusy Książęce }\end{array}$ & 6 \\
\hline 1673 & Malbork (miasto, zamek), Żuławy, Prusy Górne & 4 \\
\hline 1674 & $\begin{array}{c}\text { Malbork (miasto, zamek, przedmieścia), Kałdowo (folwark zamkowy), } \\
\text { Piaski (folwark zamkowy), Żuławy, Kościeleczki (Wielkie Żuławy } \\
\text { Malborskie), Nowy Staw (miasto, Wielkie Żuławy Malborskie), } \\
\text { Prusy Górne }\end{array}$ & 9 \\
\hline 1675 & $\begin{array}{l}\text { Kałdowo (folwark zamkowy), Kościeleczki, Palczewo (Wielkie Żuławy } \\
\text { Malborskie), Wielbark (obecnie Malbork-Wielbark), Prusy Książęce }\end{array}$ & 5 \\
\hline 1676 & $\begin{array}{c}\text { Malbork (miasto, zamek), Nowy Staw (miasto, Wielkie Żuławy Malborskie), } \\
\text { Prusy Książęce }\end{array}$ & 4 \\
\hline 1677 & $\begin{array}{c}\text { Malbork (przedmieścia), Kościeleczki (Wielkie Żuławy Malborskie), } \\
\text { Cyganek (Wielkie Żuławy Malborskie), Gościszewo, Dzierzgoń, Prusy } \\
\text { Książęce }\end{array}$ & 6 \\
\hline 1678 & $\begin{array}{l}\text { Malbork (zamek, przedmieścia), Kamionka (folwark zamkowy, } \\
\text { Wielkie Żuławy Malborskie), Grzymała, Żuławy, Prusy Górne }\end{array}$ & 6 \\
\hline \multirow[t]{2}{*}{1679} & Malbork (zamek, przedmieścia), Żuławy, Prusy Górne & 4 \\
\hline & razem & 103 \\
\hline
\end{tabular}

Źródło: Series eorum (Załącznik źródłowy).

Na podstawie danych zawartych w tab. 1 ustalono, że jezuici malborscy odbyli w omawianym okresie 103 misje, pełniąc posługę duszpasterską w 18 kościołach i parafiach na obszarze oficjałatu pomezańskiego (zob. tab. 2). Zatem na podstawie Series eorum można ustalić maksymalnie 11 misji rocznie (w $1666 \mathrm{roku})^{62}$. Jest to z pewnością liczba zaniżona, biorąc pod uwagę wykazaną przez wcześniej wymienione źródła liczbę17-19 misji rocznych ${ }^{63}$. Odpowiedź na wcześniej sformułowane pytanie musi być zatem negatywna, pełniejszy obraz uzyskujemy jedynie w kwestii lokalizacji odbywanych misji. Ustalono, że odbywały się one w kościołach, niektórych opuszczonych, innych jedynie nominalnie obsadzonych, w czterech miastach (Malbork, Nowy Staw, Sztum i Dzierzgoń) i czternastu innych miejscowościach w diecezji pomezańskiej (tab. 2).

62 Wynika to z faktu, że jedynie w niewielu przypadkach w Series eorum podawano miejsce nawrócenia danej osoby.

63 Tym bardziej że np. w roku 1683 dodatkowo obowiązywał zakaz biskupi odbywania misji w diecezji, a mimo to odbyło się ich 19 - zob. Pomezańskie powizytacyjne zarządzenie diecezjalne z 15 maja 1683 - ADP, C. 23, k. 55-61v.; thum. pol. W. Zawadzki, Duchowieństwo katolickie oficjałatu pomezańskiego w latach 1525-1821, t. 1, Elbląg 2009, s. 315. 
Tab. 2. Kościoły, w których jezuici malborscy pełnili posługę duszpasterską podczas misji odbywanych w latach 1662-1679 na podstawie Series eorum

\begin{tabular}{|c|c|c|c|c|}
\hline $\begin{array}{l}\text { archiprezbiterat } \\
\text { malborski }{ }^{1}\end{array}$ & $\begin{array}{c}\text { archiprezbiterat } \\
\text { nowostawski }\end{array}$ & $\begin{array}{l}\text { archiprezbiterat } \\
\text { dzierzgoński }\end{array}$ & $\begin{array}{l}\text { archiprezbiterat } \\
\text { sztumski }\end{array}$ & $\begin{array}{c}\text { archiprezbiterat } \\
\text { żuławski }\end{array}$ \\
\hline $\begin{array}{c}\text { Malbork } \\
\text { kościół parafialny } \\
\text { św. JanaII } \\
\text { (proboszcz w pa- } \\
\text { rafi w latach } \\
\text { 1662-1663, } \\
\text { 1666-1679, ko- } \\
\text { mendariusze, je- } \\
\text { zuici)"II }\end{array}$ & $\begin{array}{c}\text { Nowy Staw } \\
\text { kościół św. } \\
\text { Mateusza } \\
\text { Apostoła (od } \\
1673 \text { nominal- } \\
\text { ny proboszcz nie } \\
\text { przebywający } \\
\text { w parafii, komen- } \\
\text { dariusze, brak } \\
\text { stałego duszpa- } \\
\text { sterstwa, jezu- } \\
\text { ici) }\end{array}$ & $\begin{array}{c}\text { Dzierzgoń } \\
\text { kościół św. } \\
\text { Katarzyny (tylko } \\
\text { proboszcz } \\
\text { 1662-1670, } \\
\text { 1670-1678, ko- } \\
\text { mendariusz } \\
1678-1685)^{\mathrm{v}}\end{array}$ & $\begin{array}{l}\text { Sztum } \\
\text { kościół św. Anny } \\
\text { (nominalny } \\
\text { proboszcz } \\
\text { od 1664, } \\
\text { komendariusz } \\
\text { 1670-1679) }\end{array}$ & $\begin{array}{l}\text { Cyganek - koś- } \\
\text { ciół św. Mikołaja } \\
\text { (proboszcz i wi- } \\
\text { kariusz)VII }\end{array}$ \\
\hline $\begin{array}{c}\text { Malbork } \\
\text { kościół zamko- } \\
\text { wy NMP z cu- } \\
\text { downym obra- } \\
\text { zem (brak stałego } \\
\text { duszpasterstwa, } \\
\text { od } 1672 \\
\text { jezuici) }\end{array}$ & $\begin{array}{c}\text { Lichnowy } \\
\text { kościół } \\
\text { św. Urszuli, nomi- } \\
\text { nalni proboszcze } \\
\text { nie przebywają- } \\
\text { cy w parafii, brak } \\
\text { stałego dusz- } \\
\text { pasterstwa } \\
\text { (1663-1670, } \\
\text { 1670-1682), ko- } \\
\text { mendariusz i mi- } \\
\text { sjonarz (1669- } \\
\text { 1673) o. Mikołaj } \\
\text { Garczyński z re- } \\
\text { zydencji malbor- } \\
\text { skiej }{ }^{\mathrm{Ix}}\end{array}$ & $\begin{array}{c}\text { Fiszewo } \\
\text { kościół św. Jana } \\
\text { Chrzciciela } \\
\text { (zrujnowany, bez } \\
\text { proboszcza } \\
\text { 1654-1676, brak } \\
\text { stałego duszpa- } \\
\text { sterstwa, jezuici) }\end{array}$ & $\begin{array}{l}\text { Gościszewo } \\
\text { kościół św. } \\
\text { Wawrzyńca zbu- } \\
\text { rzony przez } \\
\text { Szwedów w } 1626 \\
\text { roku, nominal- } \\
\text { nie parafia ist- } \\
\text { niała do } 1681 \text { r., } \\
\text { kiedy to została } \\
\text { włączona do pa- } \\
\text { rafii w Sztumie } \\
\text { (zrujnowany, bez } \\
\text { proboszcza, brak } \\
\text { stałego duszpa- } \\
\text { sterstwa, } \\
\text { jezuici) }\end{array}$ & \\
\hline $\begin{array}{l}\text { Wielbark - koś- } \\
\text { ciół, po II wojnie } \\
\text { szwedzkiej w zu- } \\
\text { pełnej ruinie } \\
\text { (jezuici)xII }\end{array}$ & $\begin{array}{c}\text { Palczewo } \\
\text { kościół NMP, } \\
\text { filia para- } \\
\text { fii w Borętach, } \\
\text { opuszczony i zruj- } \\
\text { nowany (brak sta- } \\
\text { tego duszpaster- } \\
\text { stwa, jezuici)XIII }\end{array}$ & $\begin{array}{c}\text { Jasna } \\
\text { kościół Trójcy } \\
\text { Przenajświętszej, } \\
\text { spalony podczas } \\
\text { Il wojny } \\
\text { szwedzkiej } \\
\text { i odbudowany } \\
\text { w } 1668 \text { roku } \\
\text { przez starostę } \\
\text { sztumskiego } \\
\text { Władysława } \\
\text { Kazimierza } \\
\text { Guldensterna } \\
\text { (nominalny } \\
\text { proboszcz } \\
\text { od 1668, } \\
\text { brak stałego } \\
\text { duszpasterstwa, } \\
\text { jezuici)xIv }\end{array}$ & $\begin{array}{c}\text { Pietrzwałd } \\
\text { kościół św. Trójcy } \\
\text { (zrujnowany, bez } \\
\text { proboszcza, brak } \\
\text { stałego duszpa- } \\
\text { sterstwa, jezuici) }\end{array}$ & \\
\hline
\end{tabular}




\begin{tabular}{|c|c|c|}
\hline $\begin{array}{c}\text { Kościeleczki koś- } \\
\text { ciół św. Mikołaja, } \\
\text { stała misja mal- } \\
\text { borskiej rezy- } \\
\text { dencji } \\
\text { jezuitów }{ }^{\text {xvI }}\end{array}$ & $\begin{array}{c}\text { Tychnowy } \\
\text { kościół św. } \\
\text { Jerzego } \\
\text { (bez proboszcza - } \\
\text { do } 1696 \text { roku, } \\
\text { brak stałego } \\
\text { duszpasterstwa, } \\
\text { jezuici) }\end{array}$ & \\
\hline $\begin{array}{c}\text { Stara } \\
\text { Kościelnica } \\
\text { kościół } \\
\text { filialny parafii } \\
\text { w Miłoradzu } \\
\text { św. Jerzego } \\
\text { (bez proboszcza, } \\
\text { brak stałego } \\
\text { duszpasterstwa, } \\
\text { jezuici) }\end{array}$ & & \\
\hline $\begin{array}{l}\text { Pogorzała } \\
\text { Wieś kościół } \\
\text { św. Mikołaja } \\
\text { (proboszcz od } \\
1670 \text { roku, } \\
\text { jezuici)xIx }\end{array}$ & & \\
\hline $\begin{array}{l}\text { Mątowy Wielkie } \\
\text { kościół św. } \\
\text { Piotra i Pawła } \\
\text { (nominalny } \\
\text { proboszcz } \\
\text { Bernard Sasin } \\
\text { do } 1665 \text { roku, } \\
\text { brak stałego } \\
\text { duszpasterstwa, } \\
\text { jezuici)xx }\end{array}$ & & \\
\hline
\end{tabular}

I Powstały w 1601 roku oficjałat pomezański z siedzibą w Malborku podzielony był na 5 archipezbiteratów, z których każdy składał sie z około 10 parafii na czele z archiprezbiterem (dziekanem) - M. Józefczyk, Z dziejów religijnych Pomezanii..., dz. cyt., t. 1, s. 16, 107-108.

II W. Zawadzki, Duchowieństwo katolickie..., dz. cyt., t. 1, s. 350.

III M. Józefczyk, Z dziejów religijnych Pomezanii..., dz. cyt., t. 1, s. 118-119.

IV M. Józefczyk, Z dziejów religijnych Pomezanii..., dz. cyt., t. 1, s. 174; W. Zawadzki, Duchowieństwo katolickie, dz. cyt., t. 1, s. 363-364.

V W. Zawadzki, Duchowieństwo katolickie, dz. cyt., t. 1, s. 325; M. Józefczyk, Z dziejów religijnych Pomezanii..., dz. cyt., t. 1, s. 216-217.

VI M. Józefczyk, Z dziejów religijnych Pomezanii..., dz. cyt., t. 1, s. 265; W. Zawadzki, Duchowieństwo katolickie, dz. cyt., t. 1, s. 371;

VII W. Zawadzki, Duchowieństwo katolickie, dz. cyt., t. 1, s. 323-324; M. Józefczyk, Z dziejów religijnych Pomezanii..., dz. cyt., t. 1, s. 306-307.

VIII W tym roku po raz pierwszy w źródłach dotyczących rezydencji malborskiej pojawia się funkcja prefekta świątyni zamkowej (Praefectus Templi Arcensis), którym był wówczas o. Jan Maniecki, jednocześnie kaznodzieja popołudniowy i spowiednik - Cat. Brev. 1672, k. 12v.

IX W. Zawadzki, Duchowieństwo katolickie, dz. cyt., t. 1, s. 347; M. Józefczyk, Z dziejów religijnych Pomezanii..., dz. cyt., t. 1, s. 198.

X M. Józefczyk, Z dziejów religijnych Pomezanii..., dz. cyt., t. 1,s. 239; W. Zawadzki, Duchowieństwo katolickie..., dz. cyt., t. 1, s. 333. 
XI W. Zawadzki, Duchowieństwo katolickie..., dz. cyt., t. 1, s. 336; M. Józefczyk, Z dziejów religijnych Pomezanii..., dz. cyt., t. 1, s. 265, 283.

XII M. Józefczyk, $Z$ dziejów religijnych Pomezanii..., dz. cyt., t. 1, s. 118.

XIII M. Józefczyk, $Z$ dziejów religijnych Pomezanii..., dz. cyt., t. 1, s. 169, 182.

XIV M. Józefczyk, $Z$ dziejów religijnych Pomezanii..., dz. cyt., t. 1, s. 258-259; W. Zawadzki, Duchowieństwo katolickie..., dz. cyt., t. 1, s. 336-337.

XV M. Józefczyk, Z dziejów religijnych Pomezanii ..., dz. cyt., t. 1, s. 281.

XVI M. Józefczyk, Z dziejów religijnych Pomezanii..., dz. cyt., t. 1, s. 143-145; W. Zawadzki, Duchowieństwo katolickie..., dz. cyt., t. 1, s. 340.

XVII W. Zawadzki, Duchowieństwo katolickie..., dz. cyt., t. 1, s. 374; M. Józefczyk, Z dziejów religijnych Pomezanii..., dz. cyt., t. 1, s. 292.

XVIII M. Józefczyk, Z dziejów religijnych Pomezanii.., dz. cyt., t. 1, s. 149-150; W. Zawadzki, Duchowieństwo katolickie..., t. 1, s. 368.

XIX W. Zawadzki, Duchowieństwo katolickie..., dz. cyt., t. 1, s. 366; M. Józefczyk, Z dziejów religijnych Pomezanii..., dz. cyt., t. 1, s. 157.

XX M. Józefczyk, Z dziejów religijnych Pomezanii..., dz. cyt., t. 1, s. 163; W. Zawadzki, Duchowieństwo katolickie,dz. cyt., t. 1, s. 359.

Ponadto misjonarze malborscy działali na terenach przygranicznych z Prusami Książęcymi, a także na terenie księstwa, o czym świadczą informacje zamieszczone $\mathrm{w}$ annałach $\mathrm{i}$ historiach oraz nawrócenia wśród ludności pochodzącej z położonych przy granicy miast elektorskich Prabut i Kwidzyna.

Na podstawie analizy dat dziennych i rocznych umieszczonych w wykazie przy imionach konwertytów możliwe było, wspominane jedynie ogólnie przez inne źródła, ustalenie dat i nazw świąt nakazanych, podczas których prowadzono misje i zapewne dokonywało się wyznanie wiary będące uroczystym zwieńczeniem aktu nawrócenia (tab. 3) ${ }^{64}$.

Tab. 3. Święta nakazane, podczas których wychodzono na misje w latach 1662-1679, na podstawie Series eorum

\begin{tabular}{|c|c|c|c|}
\hline Data & Święta nakazane & Liczba nawróconych & Miejsce nawrócenia \\
\hline 1 stycznia & $\begin{array}{c}\text { Święto Obrzezania } \\
\text { Pańskiego }\end{array}$ & 5 & $\begin{array}{c}\text { m.in. Przedmieścia } \\
\text { Malborka, Nowy Staw, } \\
\text { Cyganek }\end{array}$ \\
\hline 6 stycznia & $\begin{array}{c}\text { Uroczystość } \\
\text { Objawienia Pańskiego }\end{array}$ & 3 & brak informacji \\
\hline lutego & $\begin{array}{c}\text { Święto Oczyszczenia } \\
\text { Najświętszej Maryi } \\
\text { Panny }\end{array}$ & 2 & brakrmacji \\
\hline
\end{tabular}

64 Znamiennym przykładem jest nawrócenie w 1713 roku Michała Ernesta Rexina, przyszłego starosty i ekonoma malborskiego. Został on nawrócony z luteranizmu podczas nauki odbywanej w kolegium gdańskim przez tamtejszych jezuitów, ale publiczne wyznanie wiary odczytał przy ołtarzu przed przyjęciem komunii w należącym do jezuitów malborskich kościele zamkowym - AAWO, H. 11, Historia Residentiae Mariaburgensis, k. 71v. Zob. też A. Mariani, Duszpasterstwo jezuitów nieświeskich..., dz. cyt., s. 64. 


\begin{tabular}{|c|c|c|c|}
\hline 24/25 lutego & $\begin{array}{l}\text { Święto Świętego } \\
\text { Macieja Apostoła }\end{array}$ & 1 & brak informacji \\
\hline 19 marca & $\begin{array}{c}\text { Święto Świętego } \\
\text { Józefa, Oblubieńca } \\
\text { NMP }\end{array}$ & 2 & brak informacji \\
\hline 25 marca & $\begin{array}{c}\text { Święto Zwiastowania } \\
\text { Najświętszej Maryi } \\
\text { Pannie }\end{array}$ & 1 & brak informacji \\
\hline 1 maja & $\begin{array}{l}\text { Święto Świętych } \\
\text { Apostołów Filipa } \\
\text { i Jakuba (Młodszego) }\end{array}$ & 2 & Malbork przedmieścia \\
\hline 24 czerwca & $\begin{array}{c}\text { Święto Narodzenia } \\
\text { Świętego Jana } \\
\text { Chrzciciela }\end{array}$ & 1 & folwark Kałdowo \\
\hline 29 czerwca & $\begin{array}{c}\text { Święto Świętych } \\
\text { Apostołów Piotra } \\
\text { i Pawła }\end{array}$ & 1 & brak informacji \\
\hline 26 lipca & $\begin{array}{l}\text { Święto Świętej Anny, } \\
\text { Matki NMP }\end{array}$ & 1 & Jasna \\
\hline 10 sierpnia & $\begin{array}{c}\text { Święto Świętego } \\
\text { Wawrzyńca, Diakona } \\
\text { i Męczennika }\end{array}$ & 2 & brak informacji \\
\hline 24 sierpnia & $\begin{array}{c}\text { Święto Świętego } \\
\text { Bartłomieja Apostoła }\end{array}$ & 1 & Lichnowy \\
\hline 8 września & $\begin{array}{c}\text { Święto Narodzenia } \\
\text { Najświętszej Maryi } \\
\text { Panny }\end{array}$ & 5 & $\begin{array}{l}\text { m.in. pogranicze Prus } \\
\text { Książęcych }\end{array}$ \\
\hline 21 września & $\begin{array}{c}\text { Święto Świętego } \\
\text { Mateusza Apostoła } \\
\text { i Ewangelisty }\end{array}$ & 1 & $\begin{array}{l}\text { pogranicze Prus } \\
\text { Książęecych }\end{array}$ \\
\hline 29 września & $\begin{array}{l}\text { Święto Świętego } \\
\text { Michała Archanioła }\end{array}$ & 2 & $\begin{array}{c}\text { Malbork zamek, } \\
\text { pogranicze Prus } \\
\text { Książęcych }\end{array}$ \\
\hline 1 listopada & $\begin{array}{l}\text { Święto Wszystkich } \\
\text { Świętych }\end{array}$ & 1 & brak informacji \\
\hline 30 listopada & $\begin{array}{l}\text { Święto Świętego } \\
\text { Andrzeja Apostoła }\end{array}$ & 2 & brak informacji \\
\hline 21 grudnia & $\begin{array}{l}\text { Święto Świętego } \\
\text { Tomasza Apostoła }\end{array}$ & 2 & brak informacji \\
\hline 25 grudnia & Boże Narodzenie & 3 & m.in. Malbork \\
\hline 26 grudnia & $\begin{array}{c}\text { Święto Świętego } \\
\text { Szczepana, } \\
\text { Pierwszego } \\
\text { Męczennika }\end{array}$ & 3 & $\begin{array}{c}\text { Tychnowy, Bystrzec } \\
\text { (Biały Dwór) }\end{array}$ \\
\hline 31 grudnia & $\begin{array}{l}\text { Święto Świętego } \\
\text { Sylwestra I, Papieża }\end{array}$ & 3 & m.in. Malbork \\
\hline
\end{tabular}




\begin{tabular}{|c|c|c|c|}
\hline & $\begin{array}{l}\text { święta nakazane } \\
\text { ruchome }\end{array}$ & & \\
\hline & Wielkanoc & 9 & $\begin{array}{c}\text { m.in. pogranicze } \\
\text { z Prusami Książęcymi }\end{array}$ \\
\hline & $\begin{array}{l}\text { Poniedziałek } \\
\text { Wielkanocny }\end{array}$ & 2 & brak informacji \\
\hline & Wtorek Wielkanocny & 6 & $\begin{array}{l}\text { m.in. Malbork przed- } \\
\text { mieścia }\end{array}$ \\
\hline & Boże Ciało & 5 & brak informacji \\
\hline & $\begin{array}{l}\text { Wniebowstapienie } \\
\text { Pańskie }\end{array}$ & 2 & m.in. Pogorzała Wieś \\
\hline & $\begin{array}{l}\text { Zesłanie Ducha } \\
\text { Świętego }\end{array}$ & 4 & $\begin{array}{l}\text { m.in. Kałdowo, } \\
\text { Kościeleczki }\end{array}$ \\
\hline & niedziele & 55 & $\begin{array}{c}\text { m.in. Malbork, } \\
\text { przedmieścia } \\
\text { Malborka, Wielbark, } \\
\text { Kościeleczki, Fiszewo, } \\
\text { Sztum, Dzierzgoń, } \\
\text { często pogranicze } \\
\text { z Prusami Książęcymi }\end{array}$ \\
\hline razem & & 127 & \\
\hline
\end{tabular}

Źródło: Series eorum (por. Załącznik źródłowy).

Do nawróceń dochodziło również w inne święta, a nawet dni powszednie. Urban VIII konstytucją apostolską Universa per orbem z 24 września 1642 zaliczył trzy dni święta Wielkiego Tygodnia do szeregu dni powszednich, a nie świąt uroczystych (natomiast do świąt nakazanych zaliczał się odtąd np. Wtorek Wielkanocny). Jezuici malborscy prowadzili więc działania misyjne w dni świąteczne Wielkiego Tygodnia, tzn. Niedzielę Palmową, Wielki Czwartek, Piątek i Sobotę. Inne święta wspomniane w Series eorum to Popielec, Święto Narodzenia Najświętszej Maryi Panny czy Wigilia Bożego Narodzenia. Do licznych nawróceń dochodziło też w soboty i wigilie świąt nakazanych.

\section{Pochodzenie terytorialne, wyznanie i liczebność konwertytów}

W Series eorum wskazano pochodzenie 168 z 514 wyliczonych w dokumencie konwertytów, co stanowi zaledwie 33 proc. (tab. 4). W przypadku osób, 
które można uznać za „miejscowe”, miejsce pochodzenia może się pokrywać $\mathrm{z}$ miejscem nawrócenia, albowiem $\mathrm{w}$ ich parafiach działali jezuici malborscy.

Tab. 4. Pochodzenie terytorialne konwertytów malborskich

\begin{tabular}{|c|c|c|c|}
\hline Miejsce pochodzenia & Liczba & Miejsce pochodzenia & Liczba \\
\hline Malbork miasto & 19 & Cyganek & 1 \\
\hline Malbork przedmieścia & 17 & Czechy & 1 \\
\hline Malbork zamek & 10 & Dąbrowa & 1 \\
\hline Malbork podzamcze & 4 & Gościszewo & 1 \\
\hline Malbork łącznie: & 50 & Jasna & 1 \\
\hline Prusy Książęce & 31 & Kaczynos & 1 \\
\hline Kościeleczki & 5 & Lębork & 1 \\
\hline Królewiec (Königsberg) & 5 & Lubeka & 1 \\
\hline Nowy Staw & 4 & Mątki & 1 \\
\hline Dzierzgoń & 4 & Mątowy & 1 \\
\hline Nowa Wieś Malborska & 3 & Pawłowo & 1 \\
\hline Pomorze & 3 & Pietrzwałd & 1 \\
\hline Stogi (Heybuden) & 3 & Palczewo & 1 \\
\hline Wielkie Ks. Lit. & 3 & Prusy Królewskie & 1 \\
\hline Brunszwik & 2 & Puck & 1 \\
\hline Dania & 2 & Rakowiec & 1 \\
\hline Elbląg & 2 & Ruś & 1 \\
\hline Fiszewo & 2 & Saksonia & 1 \\
\hline Gdańsk & 2 & Stara Kościelnica & 1 \\
\hline Kominki (Kamionka) & 2 & Starogard & 1 \\
\hline Kałdowo & 2 & Szkocja & 1 \\
\hline Lichnowy & 2 & Sztum & 1 \\
\hline Piaski & 2 & Tychnowy & 1 \\
\hline Prabuty & 2 & Pogorzała Wieś & 1 \\
\hline Szwecja & 2 & Węgry (wieś) & 1 \\
\hline Wielbark & 2 & Wielkopolska & 1 \\
\hline Brandenburgia & 1 & Zalewo & 1 \\
\hline Brodnica & 1 & Żuławy Gdańskie & 1 \\
\hline Chełmno & 1 & Żuławy Malborskie & 1 \\
\hline Chojnice & 1 & & \\
\hline Razem & 168 & & \\
\hline
\end{tabular}

Źródło: Series eorum. 
Do 96 osób, które należy uznać za miejscowych, zaliczają się stanowiący największą grupę konwertyci pochodzący z Malborka (50 osób), z obszaru ekonomii malborskiej (tzn. z Wielkich i Małych Żuław Malborskich-28 osób) i województwa malborskiego (18 osób). W przypadku pozostałych konwertytów miejsce pochodzenia nie może pokrywać się z miejscem nawrócenia. Dotyczy to zarówno osób z innych rejonów Prus Królewskich (15 osób), Korony (2), Wielkiego Księstwa Litewskiego (1) i z zagranicy (11 osób) ${ }^{65}$. Na podstawie różnych przesłanek można przyjąć z dużą dozą prawdopodobieństwa, że również konwertyci zamiejscowi byli nawróceni w Malborku, jak chociażby żołnierze (służący w załodze zamkowej), służba, rzemieślnicy, wędrowni żebracy, imigranci z Wielkiego Księstwa Litewskiego itp ${ }^{66}$. Pozostałe osoby których pochodzenie podano, wywodziły się terytorium Prus Książęcych (41 osób) i zostały nawrócone podczas misji ludowych.

W tekście źródła znajdujemy powtarzające się łacińskie określenia wyznania nawróconych osób, takie jak heretyk (haereticus), luteranin (lutheranus), kalwinista (calvinista), mennonita (mennonista), apostata (apostata) i schizmatyk (schismaticus, graecus). Heretyk oznaczał w XVII wieku „wyznawcę twierdzeń religijnych wywodzących się z chrześcijaństwa, niezgodnych z nauką Kościoła katolickiego"67. W omawianym dokumencie oraz w innych źródłach jezuickich określenie to stosowano wobec dwóch głównych wyznań protestanckich, tzn. luteran oraz kalwinistów, i często używano zamiennie ${ }^{68}$. Co ciekawe, nie określano nim mennonitów, zaliczających się przecież również do wyznań protestanckich. W Series eorum znajdujemy zatem wzmianki o nawróceniu 24 maja 1670 roku jakiegoś chłopaka w wieku 17 lat z przedmieść Malborka i o służącej z Prus Książęcych (10 kwietnia 1672) mających heretyckich rodziców ${ }^{69}$. Wymieniony jest też niejaki Pawel, arendarz jezuitów malborskich z Nowego Stawu, rozgrzeszony z herezji 1 stycznia 1676 roku, a także Jakub, zaufany sługa ekonoma malborskiego, rozgrzeszony z herezji 2 września 1676 roku, i inni. W niektórych przypadkach konfesja „heretyków” jest doprecyzowana. Np. mężczyzna o imieniu Jerzy

65 Dla dwóch pozostałych konwertytów miejsca pochodzenia nie udało się zidentyfikować.

66 Np. na zakończenie listy konwertytów w roku 1665 w Series eorum znajduje się informacja o nawróconych - oprócz wcześniej wymienionych konwertytów malborskich - dodatkowo 7 osobach, podczas gdy w rzeczywistości w poprzedzającym tę informację tekście przy wielu nazwiskach nie podano ani Malborka, ani żadnego innego miejsca nawrócenia.

67 B. Walczak, Mały stownik etymologiczno-historyczny kacerstwa polskiego, „Poznańskie Studia Polonistyczne, Seria Literacka" 3 (1996): Innowiercy, odszczepieńcy, herezje, s. 15-16.

68 S. Kościelak, Konwertyci elblascy..., dz. cyt., s. 186.

69 Wszystkie odniesienia do wymienionych osób zob. Załacznik źródlowy. 
konwertowany był z luterańskiej herezji 20 marca 1664 roku $^{70}$, a Paweł, poddany burgrabiego malborskiego, został wraz z córką rozgrzeszony z herezji luterańskiej 9 czerwca roku 1678. Zamiennie dla określenia „herezja luterańska" stosowano też określenie „sekta luterańska"71.

Luteranie, stanowiący najliczniejszą grupę wyznaniową w Malborku, są konfesją najczęściej wymienianą wprost w Series eorum ${ }^{72}$. Np. Dawid, syn luteranina, nawrócony został 20 kwietnia 1675 roku, Dorota luteranka 2 czerwca 1675 roku, kupiec Krzysztof, luteranin - 24 listopada 1675 roku itp. Można także z dużą dozą prawdopodobieństwa założyć, że nawrócone osoby bez określonego szczegółowo w wykazie wyznania to również luteranie. Pośrednie potwierdzenie tego przypuszczenia znajdujemy w kronice rezydencji malborskiej. W Series eorum pod rokiem 1665 znajduje się mianowicie informacja, że „Praeter praedictos Mariaeburgi convertos Septem alii in Pagis, opera Patris Missionarii orthodoxam fidem suscepere"73. Tę samą informację, ale z podaniem wyznania nawróconych, podaje kronika rezydencji: „In Pagis septem alii praeter numeratos fidem Catholicam abiectae Lutherano dogmate suscepere"74.

$\mathrm{W}$ przeciwieństwie do luteran, $\mathrm{k}$ alw in i śc i stanowili w Malborku nietolerowaną, również przez tych pierwszych, mniejszość, popularną jedynie w najzamożniejszych kręgach patrycjatu miejskiego ${ }^{75}$. W Series eorum wskazywani są niezmiernie rzadko. Tekst wspomina kalwinistę kapitana Karola Homeltana w 1665 roku, mieszczanina sztumskiego, kalwinistę z Anglii Thomasa Molingsa 4 listopada 1668 roku, kalwinistę Jana Rotha 19 grudnia 1670 roku, Katarzynę Frezerin (zapewne Frezer), kapitanową ze Szkocji w 1672 roku itp. Jak wykazano w tabeli 5, ,heretycy”, czyli łącznie traktowani luteranie i kalwiniści, stanowili najliczniejszą grupę konwertytów w latach 1662-1679: czyli 404 osoby na 514 (79 proc.) nawróconych wymienionych imiennie w Series eorum ${ }^{76}$.

70 W kronice jezuitów malborskich uściślono, że byli to predykant kalwiński i luterański Jerzy Orlicz wraz z żoną i córką - AAWO, H. 11, Historia Residentiae Mariaburgensis, k. 13v.

71 Zob. B. Walczak, Mały stownik etymologiczno-historyczny..., dz. cyt., s. 21-23.

72 S. Kościelak, Dzieje wyznaniowe Prus Królewskich w XVI-XVIII w., dz. cyt., s. 209, 220.

73 Zob. Załacznik źródłowy, rok 1665.

74 AAWO, H. 11, Historia Residentiae Mariaburgensis, k. 14v.

75 Ch. Hartknoch, Preussische Kirchen-Historia, Danzig 1686, s. 1072-1074; H. Eckerdt, Geschichte des Kreises Marienburg, Marienburg 1868, s. 100; W. Zawadzki, Zakony w Pomezanii w XVIIXIX w., Olsztyn-Elbląg 2013, s. 4.

76 Dla celów porównawczych liczba luteran i kalwinistów została tutaj podana łącznie ze względu na fakt, że w ten sposób podawano ją przeważnie w innych źródłach jezuickich (kroniki, annały) - zob. tab. 7. 
Tab. 5. Liczba nawróconych przez jezuitów rezydencji malborskiej według wyznania, za: Series eorum

\begin{tabular}{|c|c|c|c|c|}
\hline Rok & $\begin{array}{c}\text { Ewangelicy }{ }^{\mathrm{I}} \\
\text { (luteranie i kalwiniści) }\end{array}$ & Prawosławni & Apostaci & Menonici \\
\hline 1662 & 18 & 2 & 3 & - \\
\hline 1663 & 3 & - & 3 & - \\
\hline 1664 & 19 & - & 2 & - \\
\hline 1665 & $>35$ & - & 2 & 1 \\
\hline 1666 & $>30$ & - & 1 & - \\
\hline 1667 & >19 & 2 & 2 & 2 \\
\hline 1668 & 40 & 26 & - & - \\
\hline 1669 & 44 & 40 & 8 & - \\
\hline 1670 & $>23$ & 1 & 1 & - \\
\hline 1671 & 14 & - & 1 & - \\
\hline 1672 & 21 & - & - & - \\
\hline 1673 & 16 & - & 1 & - \\
\hline 1674 & 27 & 2 & - & - \\
\hline 1675 & 37 & - & 3 & - \\
\hline 1676 & 18 & 2 & 1 & - \\
\hline 1677 & 13 & - & 1 & - \\
\hline 1678 & 15 & - & 3 & - \\
\hline 1679 & 12 & - & - & - \\
\hline Razem & $>404$ & 75 & 32 & 3 \\
\hline
\end{tabular}

I Do tej grupy zaliczono w niniejszym wykazie zarówno osoby wyraźnie określone w tekście jako luteranie lub kalwiniści, jak i pozostałe osoby bez określonego wyznania.

Źródło: Series eorum.

Kolejną co do liczebności grupę konwertytów w Malborku stanowili schizmatycy (75 osób). Sformułowaniem tym posługiwano się dla określenia wyznawców Kościoła wschodniego, czyli prawosławnego ${ }^{77}$. Informacje o nich są bardzo skąpe. Schizmatyk Maciej Branicki został przekonwertowany w 1662 roku, schizmatyk Jan nawrócony 17 lutego 1669 roku,

77 B. Walczak, Maty słownik etymologiczno-historyczny..., dz. cyt., s. 19-21. 
schizmatyk Marcin - 7 kwietnia 1669 roku, schizmatyczka Katarzyna w 1674 roku, Wojciech - schizmatyk z Prus Książęcych - 25 kwietnia 1676 roku itp.

Obecność wyznawców Kościoła wschodniego w Malborku i okolicach jest bardzo ciekawym zagadnieniem, wymagającym odrębnych studiów ${ }^{78}$. Jakkolwiek zaledwie jeden „schizmatyk” nawrócony przez jezuitów malborskich wspomniany jest w annałach z 1642 roku, tak po II wojnie szwedzkiej wydają się oni liczniejsi na tym terenie. Ich obecność w Prusach Królewskich może być np. wynikiem licznej migracji z Wielkiego Księstwa Litewskiego, najpierw na terytorium Prus Książęcych i stamtąd do Prus Królewskich, zapoczątkowanej w 1654 najazdem moskiewskim ${ }^{79}$.

Inną kategorią konwertytów są a p o s ta c i (32), traktowani w źródłach jezuickich jak odrębna grupa wyznaniowa. Słowo to odnosiło się do osób niepraktykującących, oznaczało „odszczepieńca, odstępcę od wiary”, zarówno od katolicyzmu, jak i luteranizmu ${ }^{80}$. W wykazie znajdujemy zatem np. niejakiego Jana, syna tkacza, luteranina i apostatę nawróconego 6 października 1675 roku, Andreasa, młodzieńca ze Szwecji (zapewne więc luteranina) nawróconego $\mathrm{z}$ apostazji 1 czerwca 1664 roku, jak również Piotra, nieletniego apostatę od wiary katolickiej, przywróconego na łono Kościoła 18 grudnia 1678 roku. Trwanie w apostazji, czyli brak uczestnictwa w mszy świętej oraz nieprzystępowanie do sakramentów i niepraktykowanie codziennej modlitwy, obejmowało różnej długości okresy. Anna z Mątek powróciła do Kościoła po 20 latach apostazji, pewna szlachcianka nawrócona 10 sierpnia 1663 roku - po 11 latach, Marcin - apostata od 6 równych lat, nawrócony 24 listopada 1663 roku, jakiś apostata, nigdy nierozgrzeszony, dołączył do Kościoła 29 grudnia 1669 roku itp.

Ostatnią grupę wyznaniową w Series eorum stanowią m e n o n i c i, wymienieni w źródle jedynie dwukrotnie. Młodzieniec o nazwisku Abraham Paterson przyjął chrzest z rąk kaznodziei niemieckiego w 1665 roku, a Olęder ze Stogów Krystian Schultz został nawrócony wraz z żoną Gertrudą 18 marca

78 Rozważania na ten sam temat snuł już wcześniej S. Kościelak, Jezuici w Gdańsku..., dz. cyt., s. 263-264, który wskazywał na możliwość migracji z południowo-wschodnich rubieży Rzeczpospolitej w wyniku powstań kozackich, w szczególności powstania Chmielnickiego.

79 Szerzej na ten temat zob. H. Sahanowicz, Wychodźcy z Wielkiego Księstwa Litewskiego w Prusach 1656 roku, „Lituano-Slavica Posnaniensia, Studia Historica” 9 (2003), s. 239-245; S. Augusiewicz, Spis uchodźców z Wielkiego Księstwa Litewskiego w Prusach Książęcych w latach 1655-1656 w zbiorach Geheimes Staatsarchiv Preussicher Kulturbesitz w Berlinie, „Komunikaty Mazursko-Warmińskie” 1 (2011), s. 97-181.

80 Zob. S. Kościelak, Jezuici w Gdańsku, dz. cyt., s. 260; S. Kościelak, Konwertyci elblascy..., dz. cyt., s. 186; B. Walczak, Maly stownik etymologiczno-historyczny ..., dz. cyt., s. 16-18. 
$1667 \mathrm{roku}^{81}$. Mennonici - ze względu na hermetyczność wyznaniową i brak organizacji kościelnej, niewielką wówczas liczebność na obszarze Żuław Malborskich oraz izolację w społeczeństwie Prus Królewskich - stanowili środowisko trudne do spenetrowania przez misjonarzy jezuickich.

Tab. 6. Liczba nawróconych przez jezuitów rezydencji malborskiej według wyznania, na podstawie Annuae et Historiae Poloniae

\begin{tabular}{|c|c|c|c|c|c|}
\hline Rok & $\begin{array}{c}\text { Ewangelicy } \\
\text { (luteranie i kalwiniści) }\end{array}$ & Prawosławni & Apostaci & Menonici & Ateiści \\
\hline 1662 & 15 & 2 & - & - & 1 \\
\hline 1663 & 4 & - & 5 & - & - \\
\hline 1664 & 25 & 4 & 3 & - & - \\
\hline 1665 & 38 & - & - & 1 & - \\
\hline 1666 & 41 & 24 & - & - & - \\
\hline 1667 & - & - & - & - & - \\
\hline 1668 & - & - & - & - & - \\
\hline 1669 & 53 & 44 & 8 & - & - \\
\hline 1670 & 30 & 3 & 3 & - & - \\
\hline 1671 & 29 & 2 & 4 & - & - \\
\hline 1672 & 39 & - & - & - & - \\
\hline 1673 & 19 & 3 & 5 & - & - \\
\hline 1674 & 39 & - & - & - & - \\
\hline 1675 & - & - & - & - & - \\
\hline 1676 & - & - & - & - & - \\
\hline 1677 & 38 & 6 & 9 & - & - \\
\hline 1678 & $<75$ & - & 3 & - & - \\
\hline 1679 & $<75$ & - & 3 & - & - \\
\hline Razem & $<520$ & 88 & 43 & 1 & 1 \\
\hline
\end{tabular}

Jeżeli chodzi o liczebność konwertytów z poszczególnych grup wyznaniowych (tab. 7), jest ona różnie podawana w odmiennych źródłach jezuickich

81 Zapewne tenże wspomniany w AAWO, H. 11, Historia Residentiae Mariaburgensis, k. 14; jezuitą udzielającym chrztu Patersonowi był pochodzący z Prus Królewskich o. Jerzy Treug, wówczas kaznodzieja niemiecki w Malborku. 
dotyczących tego samego okresu. Dane pozyskane z Series eorum porównano $z$ danymi przedstawionymi $w$ rocznikach $i$ historiach rezydencji malborskiej, które nie zachowały się niestety w komplecie. Szczególne znaczenie mają tutaj annały, w których regularnie podawano liczbę konwertytów i udzielonych sakramentów. Dane takie bardzo rzadko znajdowały się w Historiae Poloniae i wyrywkowo w Historiae Residentiae. Jak wykazano niedawno, to ostatnie źródło pisane było ze sporej perspektywy czasowej, zapewne w oparciu o sprawozdania rezydencji malborskiej zawarte w Historiae Poloniae, które też są niekompletne ${ }^{82}$.

Tab. 7. Liczba konwertytów w Malborku w latach 1662-1679 według różnych źródeł jezuickich

\begin{tabular}{|c|c|c|c|}
\hline Rok & $\begin{array}{l}\text { Liczba konwertytów } \\
\text { według Series eorum }\end{array}$ & $\begin{array}{l}\text { Liczba konwertytów } \\
\text { według Historiae } \\
\text { Residentiae }\end{array}$ & $\begin{array}{c}\text { Liczba konwertytów } \\
\text { według Annuae et } \\
\text { Historiae Poloniae }\end{array}$ \\
\hline 1662 & 23 & - & 18 \\
\hline 1663 & 6 & - & 9 \\
\hline 1664 & 21 & 26 & 32 \\
\hline 1665 & $>38$ & 41 & 39 \\
\hline 1666 & $>31$ & 40 & 65 \\
\hline 1667 & $>25$ & 40 & - \\
\hline 1668 & 66 & 65 & - \\
\hline 1669 & 92 & 105 & 105 \\
\hline 1670 & $>24$ & 40 & 36 \\
\hline 1671 & 15 & 55 & 35 \\
\hline 1672 & 21 & 22 & 39 \\
\hline 1673 & 17 & 14 & 27 \\
\hline 1674 & 29 & 30 & 39 \\
\hline 1675 & 40 & 46 & - \\
\hline 1676 & 21 & - & - \\
\hline 1677 & 14 & - & 53 \\
\hline 1678 & 18 & - & $<78^{\mathrm{I}}$ \\
\hline 1679 & 12 & - & $<78$ \\
\hline Razem: & $>514$ & 524 & $<653$ \\
\hline
\end{tabular}

I W latach 1678-1681 rozgrzeszono z herezji (częściowo luterańskiej, częściowo kalwińskiej) około 300, z apostazji 12. Daje to średnio ok. 78 osób rocznie przez 4 lata.

82 R. Panfil, Starania Stanistawa Kuklińskiego ..., dz. cyt., s. 174-179. 
Źródło: Series eorum; AAWO, H. 11, Historia Residentiae Mariaburgensis, k. ARSI, Pol. 53, Annuae Provinciae Polonae (APP) 1662, Residentiae Mariaeburgensis, Choinecensis, Valcensis, k. 131; APP 1663, Mariaeburg. Resid., k. 137v.; APP 1664, Resid. Mariaeburg., k. 145; APP 1665, Resid. Mariaeburg., k. 152; APP 1666, Mariaeburg. Resid., k. 179; APP 1669, Mariaeburg. Resid., k. 196v.-197; ARSI, Pol. 54, APP 1670, Mariaeburg. Resid., k. 3; APP 1671, Mariaeburg. Resid., k. 12; APP 1672, Mariaeburg. Resid., k. 94; APP 1673, Mariaeburg. Resid., k. 99; APP 1673, Mariaeburg. Resid., k. 99; APP 1677/1678, Resid. Mariaeburg., k. 211; ARSI, Pol. 55, Historiae Residentiae Mariaeburgensis Societatis Jesu ab anno 1678 ad 1681, k. 33v.

Zestawienie niepełnych informacji z Series eorum z danymi z roczników wyraźnie obrazuje rozbieżności, jeśli chodzi o podane w obydwu źródłach liczby. Według tego pierwszego w latach 1662-1679 nawrócono nie mniej niż 404 luteran i kalwinistów (heretyków), według drugiego było ich nie więcej niż 520. Wydaje się, iż nie jest to poważna rozbieżność, ponieważ różnica wynosi w przybliżeniu 7 osób rocznie. Biorąc pod uwagę pojawiające w Series eorum informacje, że byli jeszcze inni konwertyci, których imion i liczebności z jakichś powodów nie odnotowano ${ }^{83}$, niezgodność ta jest akceptowalna $^{84}$. Jeśli chodzi o pozostałe grupy, to liczby również są zbliżone, mieszcząc się w przedziale od nie mniej niż 75 do nie mniej niż 88 prawosławnych, nie mniej niż 32 do nie mniej niż 43 apostatów oraz nie mniej niż 1 do nie mniej niż 3 mennonitów. Ogólną liczbę nawróceń dokonanych przez jezuitów malborskich w omawianym okresie starano się obliczyć z kolei na podstawie 3 źródeł: Series eorum, Historiae Residentiae i Annuae et Historiae Poloniae (zob. tabela poniżej). Również tutaj obserwujemy spore rozbieżności. Najmniejszą łączną liczbę nawróceń podaje ponownie Series eorum (nie mniej niż 514), następnie bardzo zbliżoną Historiae Residentiae (524) i wreszcie znacznie wyższą annały i roczniki Prowincji Polskiej (nie więcej niż 653). Ponownie trzeba w tym miejscu przypomnieć o niekompletności tych źródeł, szczególnie kroniki rezydencji malborskiej, w której brakuje danych z roczników 1662, 1663, 1676-1679, a także annałów i roczników z brakującymi latami 1668, 1669, 1675 i 1676. Podsumowując powyższe, należy stwierdzić, że ustalenie rzeczywistej liczby nawróceń dokonanych przez jezuitów rezydencji malborskiej w latach 1662-1679 pomimo bogactwa źródeł jest niemożliwe. Na podstawie danych, którymi dysponujemy, można jedynie stwierdzić, że liczba ta zawiera się w przedziale nie mniej niż 514 i nie

83 Praeter praedictos tres alii sunt Mariaeburgi conversi quorum nomina non sunt annotata (1664), Praeter nominatos plures alii sunt conversi in Missionibus (1666), Plures Sunt S. Matri Ecclesiae aggregati non annotati (1667) - Series eorum, k. 263, 264v.-266.

84 Należy jednak pamiętać i brać pod uwagę brak w Annuae et Historiae Poloniae czterech roczników z lat 1668, 1669, 1675 i 1676, jak również wykazaną niekompletność wykazu Series eorum. 
więcej niż 653 osób w przeciągu 18 lat, co daje nie mniej niż 28 i nie więcej niż 36 konwersji rocznie.

Tab. 8. Liczba nawróceń w innych placówkach jezuickich w Prusach Królewskich oraz w Wałczu w latach 1662-1679

\begin{tabular}{|c|c|c|c|c|c|c|}
\hline Rok & $\begin{array}{c}\text { Liczba kon- } \\
\text { wertytów } \\
\text { Gdańsk }^{\text {I }}\end{array}$ & $\begin{array}{l}\text { Liczba kon- } \\
\text { wertytów } \\
\text { Bydgoszcz }^{\text {II }}\end{array}$ & $\begin{array}{c}\text { Liczba kon- } \\
\text { wertytów } \\
\text { Chojnice }\end{array}$ & $\begin{array}{l}\text { Liczba kon- } \\
\text { wertytów } \\
\text { Grudziądz }^{\text {IV }}\end{array}$ & $\begin{array}{c}\text { Liczba kon- } \\
\text { wertytów } \\
\text { Toruńv }^{v}\end{array}$ & $\begin{array}{c}\text { Liczba kon- } \\
\text { wertytów } \\
\text { Wałcz }^{\text {VI }}\end{array}$ \\
\hline 1662 & 30 & 6 & 8 & 12 & 22 & 29 \\
\hline 1663 & 46 & 3 & 19 & 8 & 6 & 8 \\
\hline 1664 & 49 & 8 & 16 & 5 & 21 & 17 \\
\hline 1665 & 25 & 10 & 20 & - & - & 32 \\
\hline 1666 & 48 & 4 & 21 & - & - & 6 \\
\hline 1667 & 49 & - & - & - & - & - \\
\hline 1668 & 28 & - & - & - & - & - \\
\hline 1669 & 32 & 9 & 8 & 10 & 8 & 15 \\
\hline 1670 & 25 & - & 11 & - & 9 & 132 \\
\hline 1671 & 36 & 5 & 14 & 9 & 9 & 78 \\
\hline 1672 & 17 & - & 22 & 31 & 18 & 20 \\
\hline 1673 & - & 7 & 21 & 4 & - & 40 \\
\hline 1674 & 17 & 6 & 17 & - & 32 & 50 \\
\hline 1675 & 34 & - & 13 & - & - & 50 \\
\hline 1676 & 47 & 17 & 24 & - & 3 & 43 \\
\hline 1677 & - & - & 10 & - & 6 & - \\
\hline 1678 & 70 & 7 & 12 & 2 & 6 & 2 \\
\hline 1679 & 27 & 4 & 14 & 3 & 3 & - \\
\hline Razem: & 580 & 86 & 250 & 84 & 143 & 522 \\
\hline
\end{tabular}

I S. Kościelak, Jezuici w Gdańsku..., dz. cyt., s. 266, tab. 27. W Series eorum znajduje się podsumowanie zbiorcze podające liczbę osób nawróconych przez jezuitów z kolegium gdańskiego (k. 258v.). Dane te znacznie przewyższają podaną tutaj liczbę 580 nawróceń: 1293 heretyków (luteran i kalwinistów), 46 apostatów, 85 schizmatyków, 12 menonitów, 3 arian, 1 Żyd. S. Kościelak uznał te dane w przypadku ,heretyków” za znacznie zawyżone - S. Kościelak, Jezuici w Gdańsku..., dz. cyt., s. 260, 266, tab. 27.

II ARSI, Pol. 53, Series eorum, k. 252v.-253; ARSI, Pol. 53, Annuae Provinciae Polonae (APP) 1663, Collegia Barense, Bidgostiense, Brestense, k. 135; APP 1664, Coll. Bidg., k. 141; APP 1665, Coll. Bidg., k. 149; APP 1666, Bidg. Colleg., k. 173; APP 1669, Colleg. Bidg., k. 193; ARSI, Pol. 54, APP 1673, Bidg. Colleg., k. 97; Annuae Triennales Collegii Bidgostiensis ab Anno 1675 ad 
Annum 1678 inclusive, Annus 1676, k. 193v.; ARSI, Pol. 55, APP 1678, Colleg. Bidg., k. 69; APP 1679, Colleg. Bidg., k. 69v.

III ARSI, Pol. 53, Series eorum, k. 254-255; ARSI, Pol. 53, APP 1662, Residentiae Mariaeburgensis, Choinecensis, Valcensis, k. 131; APP 1663, Choinec. Resid., k. 136v.; APP 1664, Resid. Choinec., k. 142; APP 1665, Choinec. Resid., k. 151v.; APP 1666, Resid. Choinec., k. 175; APP 1669, Choinec. Resid., k. 195; ARSI, Pol. 54, APP 1670, Choinec. Resid., k. 3; APP 1671, Choinec. Resid., k. 11v.; APP 1672, Choinec. Resid., k. 94; APP 1673, Choinec. Resid., k. 99; ARSI, Pol. 55, APP 1678, Resid. Choinec., k. 89; APP 1679, Resid. Choinec., k. 89.

IV ARSI, Pol. 53, APP 1662, Collegium Graudentinense, k. 129v.; APP 1663, Coll. Gedan. et Graud., k. 136v.; APP 1664, Coll. Graud., k. 144; APP 1669, Graud. Coll., k. 196; ARSI, Pol. 54, APP 1671, Graud. Coll., k. 12; APP 1672, Graud. Coll., k. 94; APP 1673, Graud. Coll., k. 99; ARSI, Pol. 55, APP 1678, Coll. Graud., k. 91; APP 1679, Coll. Graud., k. 91v.

V ARSI, Pol. 53, Series eorum, k. 270-dane dla lat 1676-1679; ARSI, Pol. 53, APP 1662, Collegium Torunense, k. 132v.; APP 1663, Coll. Torun., k. 139; APP 1664, Coll. Torun., k. 146; APP 1669, Torun. Coll., k. 199; ARSI, Pol. 54, APP 1670,Torun. Coll., k. 6; APP 1671,Torun. Coll., k. 15v.; APP 1672,Torun. Coll., k. 95v.; APP 1674,Torun. Coll., k. 106v.;

VI ARSI, Pol. 53, APP 1662, Residentia Mariaeburgensis, Choinecensis, Valcensis, k. 131; APP 1663, Resid. Valc., k. 139; APP 1664, Resid. Valc., k. 146; APP 1665, Resid. Valc., k. 154v.; APP 1666, Resid. Valc., k. 181v.; APP 1669, Resid. Valc., k. 199v.; Litera Annuae Residentiae Valcensis Societatis Jesu Annus Domini 1669, k. 216; ARSI, Pol. 54, APP 1670, Valc. Resid., k. 6; APP 1671, Valc. Resid., k. 16; APP 1672, Valc. Resid., k. 95v.; APP 1673, Valc. Resid., k. 101v.; APP 1674, Valc. Resid., k. 107; APP 1675, Valc. Resid., k. 229; APP 1676, Valc. Resid., k. 229v.; ARSI, Pol. 55, APP 1678, Valc. Resid., k. 111.

Jak prezentowała się działalność misyjna rezydencji malborskiej na tle osiągnięć na tym polu innych placówek jezuickich w Prusach Królewskich? Odpowiedź znajdujemy, analizując zestawione w tab. 8 dane zaczerpnięte z Series eorum i z roczników Prowincji Polskiej oraz opracowania Sławomira Kościelaka dotyczącego kolegium gdańskiego. W tabeli ujęto wszystkie domy jezuickie w Prusach Królewskich oraz rezydencję w Wałczu położoną na pograniczu Wielkopolski, Pomorza i Prus Królewskich. Uwzględniono również Wałcz, mimo iż nie leżał w Prusach Królewskich, ponieważ wymieniany był w źródłach obok Malborka, Chojnic i Grudziądza jako jedna ze stałych misji na północy Prowincji Polskiej ${ }^{85}$. Ponadto, jak wynika z katalogów rocznych i trzyletnich, w XVII wieku wielu jezuitów było stale przenoszonych po upływie pewnego czasu pomiędzy wspomnianymi czterema placówkami. Do największej liczby nawróceń doszło za sprawą jezuitów pracujących w kolegium w Starych Szkotach pod Gdańskiem (580 osób), kolejne miejsce zajmują Wałcz (522 nawróconych) i Malbork (nie mniej niż 514). Znacznie dalej plasuje się rezydencja o charakterze misyjnym w Chojnicach (250 konwersji) oraz kolegium w Toruniu (143), wreszcie na końcu należy umieścić kolegia w Bydgoszczy i Grudziądzu (odpowiednio 86 i 84 osoby). Z powyższego wynika, że rezydencja w Malborku, obok kolegium w Gdańsku, była

85 Missiones Provinciae Polonae Societatis Jesu - Cat. Trienn. 1655, k. 64-64v.; Missiones Provinciae Polonae - Cat. Brev. 1654/1655, k. 147v. 
drugim najważniejszym ośrodkiem misyjnym w Prusach Królewskich i trzecim (obok Wałcza) na północnych rubieżach prowincji polskiej.

\section{Zawód, stan i pozycja spoleczna konwertytów}

Wykonywany zawód lub zajmowaną pozycję społeczną podano w Series eorum dla 170 osób spośród 514 (33 proc.). Największą grupę stanowili ludzie o niskim statusie społecznym, tacy jak służba, rzemieślnicy zamkowi, chłopi i służba wiejska oraz żebracy i więźniowie pochodzący z podzamcza i przedmieść Malborka lub z Prus Książęcych. Wśród służby przeważały głównie młode kobiety określane w źródle najczęściej mianem służącej/ służki (34 osoby). Wymieniono też służbę i dzierżawców szlachty, urzędników zamkowych i duchowieństwa (8 osób), służbę z folwarków zamkowych oraz ich rodziny (3 osoby). Drugą najliczniejszą kategorią była służba wiejska, czyli najemni robotnicy rolni, parobkowie, dzierżawcy, których wymieniono 15, trzecią zaś rzemieślnicy i ich rodziny (27 osób). W spisie figurują też chłopi i ich rodziny (15 osób), a także ludzie z marginesu społecznego: 1 żebrak, 1 włóczęga i 1 więzień (3). Ogółem grupa ta liczyła 105 osób czyli 62 proc. nawróconych o wymienionej pozycji społecznej lub zawodzie. Pozostałe 38 proc. (65 osób) stanowiła szlachta ( 9 osób), mieszczanie i ich rodziny (10 osób), wojskowi i ich rodziny (35 osób), z których np. szeregowych żołnierzy możnaby zaliczyć do ludzi o niskim statusie społecznym; uczeni i studenci ( 3 osoby) i inni (woźny z żoną, karczmarz, 2 muzyków i predykant luterański z żoną i córką -8 osób).

Tab. 9. Pozycja społeczna i zawód konwertytów malborskich

\begin{tabular}{|c|c|c|}
\hline Pozycja społeczna, zawód & Określenie użyte w Series eorum & Liczba \\
\hline Służba & $\begin{array}{r}\text { służąca, służący, sługa ekonoma, służąca } \\
\text { wiceekonoma, poddany burgrabiego, służąca } \\
\text { burgrabiego, sługa oficjała pomezańskiego, } \\
\text { kucharz, piwowar zamkowy }\end{array}$ & 45 \\
\hline $\begin{array}{c}\text { Chłopi i ich rodziny, służ- } \\
\text { ba wiejska }\end{array}$ & $\begin{array}{r}\text { chłop, syn sołtysa, córka sołtysa, robotnik } \\
\text { rolny, parobek, dzierżawca, pracownik najemny, } \\
\text { pracowity, sługa gospodarza, gospodyni, żona } \\
\text { rybaka, mamka }\end{array}$ & 30 \\
\hline Wojskowi i ich rodziny & $\begin{array}{c}\text { kapitan, kapitanowa, kapitanowa ze Szkocji, } \\
\text { porucznik, porucznikowa, sierżant, żona sierżanta, } \\
\text { kapralowa, żołnierz, żołnierz zamkowy, żołnierz } \\
\text { brandenburski, żołnierz z Czech, żołnierz z Prus } \\
\text { Książęcych, żołnierz z Elbląga, żona żołnierza, żona } \\
\text { kanoniera, krewna żołnierza zamkowego, dobosz }\end{array}$ & 35 \\
\hline
\end{tabular}




\begin{tabular}{|c|c|c|}
\hline Rzemieślnicy i ich rodziny & $\begin{array}{c}\text { rzemieślnik, szewc, krawiec, szklarz, murarz, } \\
\text { murarz zamkowy, ślusarz, cieśla, stolarz, tkacz, } \\
\text { garncarz, rękawicznik, żona kowala, córka murarza } \\
\text { zamkowego, córka rzemieślnika, żona szewca }\end{array}$ & 27 \\
\hline Mieszczanie i ich rodziny & $\begin{array}{c}\text { mieszczanin, kupiec, córka obywatela } \\
\text { malborskiego }\end{array}$ & 10 \\
\hline Nauczyciele, studenci & nauczyciel akademicki, student & 4 \\
\hline Artyści & muzyk & 2 \\
\hline Szlachta & urodzony, urodzona, szlachcic, szlachcianka & 9 \\
\hline Duchowni & predykant luterański z żoną i córką & 3 \\
\hline Inni & karczmarz, woźny, żona woźnicy, więzień, żebrak, \\
włóczęga & 5 \\
\hline Razem & & 170 \\
\hline
\end{tabular}

Źródło: Series eorum.

\section{Wiek i płeć konwertytów}

Dane pozyskane z wykazu Series eorum nie pozwalają na ustalenie reprezentatywnego profilu wiekowego nawracanych osób. Dokładny wiek poznajemy tylko w 6 przypadkach: ogrodnik Paweł lat 46, Augustyn Reicherd lat 50 (1662), Andrzej, krawiec w Nowej Wsi Malborskiej lat 67, luteranka Marianna lat 13 (1667), chłopak z przedmieść Malborka lat 17 (1670), sześćdziesięciolatek Krzysztof Kura (1671) i jedenastoletnia córka pochodzącej z Pomorza Katarzyny, mieszkanki przedmieść Malborka (1672). W przypadku innych 75 konwertytów można, kierując się różnymi przesłankami, próbować ustalić, czy mamy do czynienia z osobami młodszymi, czy starszymi. Najprostszą wskazówką jest pojawienie się przy imieniu rzeczowników takich jak chłopiec (puer), dziewczynka (puella), panna/panienka (virgo), młodzieniec (adolescens), chłopak (juvenis), które odnoszą się do ludzi bardzo młodych. U innych młody wiek sugeruje kontekst opisu umieszczonego przy ich imionach, np. Marianna, córka pewnego rzemieślnika, Dorota, córka Davida Spotha, murarza zamkowego, Marianna Strenczówna, Anna, córka sołtysa z Fiszewa czy panna Anna, narzeczona szewca Wojciecha, sugerują młode, niezamężne kobiety pozostające pod opieką rodziców, w przeciwieństwie do tych nieco starszych, nazywanych w źródle: kobieta (mulier, więc już nie dziewczyna), zamężna (maritata, więc już nie panna), wdowa (vidua). Oczywiście status wdowy nie oznaczał automatycznie zaawansowanego wieku. Można 
się go jednak domyślać, np. w wypadku Anny z Mątek, która po 20 latach apostazji wróciła na łono Kościoła, czy Katarzyny Ptaszkowej, która uczyniła to samo po 50 latach apostazji (1665). Liczne informacje o osobach żonatych i zamężnych czy ponownym zamążpójściu sugerują co najmniej pełnoletniość. Przykładowo Krzysztof Groth, murarz żonaty, Barbara, żona żołnierza Jerzego Mansfelta, która wcześniej była żoną predykanta, zamężna Gertruda $\mathrm{z}$ folwarku Piaski albo gospodyni (więc nie panna) Marianna Poremba z Nowej Wsi Malborskiej (1674). Młodzieńcem nie był też zapewne garncarz Dawid Berent, mający żonatego syna Michała (1674), czy cieśla Jerzy, nawrócony wraz żoną, który zdążył doczekać się siódemki potomstwa (1675). Jeszcze starsi opisani są jednoznacznymi wyrażeniami, takimi jak starzec (senex) lub starucha (senicula).

Zgoła inaczej rzecz się ma w przypadku określenia płci konwertytów (tab. 10). Spośród 514 nawróconych 196 osób (38 proc.) to kobiety, 176 (34 proc.) mężczyźni, płeć pozostałych 142 „heretyków” (28 proc.) nie została ujawniona. $\mathrm{Z}$ powyższego wynika, że więcej nawróconych to kobiety i dziewczęta, mniejszość, choć niewielką, stanowili mężczyźni i chłopcy. Niestety, jak wykazano powyżej, nie jesteśmy w stanie określić udziału wiekowego w każdej z grup.

Tab. 10. Płeć konwertytów

\begin{tabular}{|c|c|c|}
\hline Rok & Konwertyci płci żeńskiej & Konwertyci płci męskiej \\
\hline 1662 & 15 & 8 \\
\hline 1663 & 4 & 9 \\
\hline 1664 & 5 & 27 \\
\hline 1665 & 11 & 14 \\
\hline 1666 & 17 & 13 \\
\hline 1667 & 12 & 6 \\
\hline 1668 & 3 & 9 \\
\hline 1669 & 12 & 15 \\
\hline 1670 & 10 & 4 \\
\hline 1671 & 11 & 9 \\
\hline 1672 & 12 & 6 \\
\hline 1673 & 11 & 2 \\
\hline
\end{tabular}




\begin{tabular}{|c|c|c|}
\hline 1674 & 15 & 14 \\
\hline 1675 & 19 & 14 \\
\hline 1676 & 11 & 10 \\
\hline 1677 & 9 & 5 \\
\hline 1678 & 10 & 3 \\
\hline 1679 & 9 & $176=34 \%$ \\
\hline Razem & $196=38 \%$ & 8 \\
\hline
\end{tabular}

Źródło: Series eorum.

\section{Motywy i okoliczności nawrócenia}

Series eorum, podobnie jak kroniki czy annały, podają pokrótce przy okazji niektórych nawróceń, zazwyczaj w sposób moralizatorski, okoliczności, w jakich do nich dochodziło. Były to zazwyczaj trudne lub uroczyste momenty życiowe, które sprzyjały nawróceniu się na katolicyzm.

\subsection{Ciężka choroba, zagrożenie życia, ciężka sytuacja życiowa.}

Obawa przed utratą życia spowodowana chorobą, wojną bądź ciążącym surowym wyrokiem sądowym stanowiła silny bodziec stymulujący do przejścia na katolicyzm ${ }^{86}$. W Series eorum opisano liczne przypadki konwersji w takich właśnie okolicznościach. 19 czerwca 1662 roku nawrócony został jakiś prawosławny, któremu w sytuacji zagrożenia życia objaśniono tajemnice

86 Strach przed śmiercią i następującym po niej sądem ostatecznym oraz oczekującymi mękami czyśćcowymi lub piekielnymi mogły być bardzo ważnym motywem nawrócenia się na katolicyzm, choć przestrogi te nie przeważały w kazaniach duchownych jezuickich XVII wieku - zob. T. Wiślicz, Pedagogika strachu $w$ Kościele potrydenckim $w$ Polsce, w: Sic erat in fatis. Studia i szkice historyczne dedykowane Profesorowi Bogdanowi Rokowi, red. E. Kościk, R. Żerelik, P. Badyna, F. Wolański, Toruń 2012, t. 1, s. 288-289; T. Wiślicz, , Jak gdyby wśród pogan lub heretyków”. Polityka potrydenckiego Kościoła wobec religii ludowej i jej osobliwości w Rzeczypospolitej, w: Staropolski ogląd świata. Rzeczypospolita między okcydentalizmem a orientalizacją. Przestrzeń wyobrażeń, red. R. Kołodziej, F. Wolański, Toruń 2009, t. 2, s. 31-42. 
wiary i wyspowiadano ${ }^{87}$. Predykant luterański Jerzy Orlicz w 1664 roku nawrócił się na katolicyzm wraz z żoną i córką w zamian za pomoc w życiu doczesnym w trudnym, powojennym okresie. 15 marca 1667 roku powrócił na łono Kościoła w śmiertelnej chorobie liczący sobie 67 lat Andrzej, krawiec z Nowej Wsi Malborskiej. W identycznej sytuacji w tym samym roku nawrócił się woźny Hans Senka, za którego przykładem podążyła 22 marca jego żona Barbara. 2 września 1676 roku rozgrzeszony z herezji został w chorobie robotnik najemny Andrzej Bąk, a 9 czerwca 1678 skazaniec o imieniu Jakub prowadzony na śmierć itp.

\subsection{Spełnienie wcześniej złożonego ślubu}

Kolejnym motywem konwersji było uroczyste ślubowanie złożone w kryzysowej sytuacji, mające doprowadzić do uleczenia, uwolnienia z niewoli lub nawet uratowania życia. Widać tutaj wyraźne nawiązanie do poprzednio wyróżnionej kategorii. Szlachcic Andrzej Kos z Bystrzca zgodnie z wcześniejszym ślubem przeszedł na katolicyzm 26 grudnia 1665 roku, kalwinista Jan Roth na skutek ślubów złożonych przed obrazem Najświętszej Marii Panny w Turowie, będąc śmiertelnie chory, nawrócony 19 grudnia 1670, przeżył. Żołnierz o imieniu Jerzy z powodu ślubu złożonego podczas wojny moskiewskiej nawrócił się 27 października 1672 roku itp.

\subsection{Nawrócenia $w$ więzieniu}

Andreas, młodzieniec ze Szwecji, zapewne jeniec wojenny, nawrócony został $\mathrm{z}$ apostazji $\mathrm{w}$ więzieniu 1 czerwca 1664 roku. Konwersjom w więzieniu podlegali jednak, jak się okazuje, nie tylko więźniowie. Przy okazji niesienia przez jezuitów posługi skazańcom nawrócona została 25 grudnia 1668 roku (a więc w Boże Narodzenie) Anna Regenborgin, córka obywatela malborskiego i zarazem żona strażnika więziennego Wilhelma Leutenanta.

\subsection{Małżeństwo i narzeczeństwo}

Do konwersji udawało się nakłonić młode pary pragnące zawrzeć związek małżeński. Służka Katarzyna nawróciła się przed ślubem 23 listopada 1669

87 Wszystkie podane niżej daty mają odniesienie w treści Załacznika źródtowego, dlatego zrezygnowano $\mathrm{z}$ dodawania przypisu do każdego cytowanego przypadku. 
roku, podobnie tego samego dnia jej siostra Anna, również przyszła panna młoda. Ponieważ do nawróceń doszło w sobotę, najprawdopodobniej obie siostry wyszły za mąż następnego dnia, w niedzielę 24 listopada. Inna Katarzyna została nawrócona dzień przed zaręczynami 6 stycznia 1669 roku, Marianna z Nowego Stawu z powodu małżeństwa 19 lipca 1670 roku, żołnierz Jan Klas z narzeczoną, wdową o imieniu Anna 21 grudnia 1673 roku w Święto Świętego Tomasza Apostoła itp.

Dokument wskazuje, że małżeństwa mieszane wyznaniowo nie należały do rzadkości. $Z$ upływem czasu jedno z niekatolickich małżonków postanawiało zmienić wyznanie. I tak pracowity Andrzej został wprowadzony na łono Kościoła przez swoją żonę w 1670 roku. Z kolei pewna niewymieniona z imienia kobieta, apostata, powróciła do Kościoła dzięki małżonkowi 1 stycznia 1671 roku w Święto Obrzezania Pańskiego. Kilka dni później, 6 stycznia (Uroczystość Objawienia Pańskiego) 1671 roku niejaka Elżbieta „wprowadzona” została do Kościoła przez męża, dodatkowo za zgodą „heretyckich" rodziców. Jeszcze inni nawracali się na katolicyzm owdowiawszy, jak np. w 1665 roku pochodzący z Chełmna szklarz Jakub, który z powodu żony przez 10 lat był luteraninem, co sugeruje, że już wcześniej mógł być katolikiem.

\subsection{Naprawa „błędów” rodziców ${ }^{88}$}

Anna, nie chcąc podążać za błędami rodziców, nawróciła się 13 kwietnia 1667 roku, Marianna - dziewczyna w wieku 13 lat, nie chcąc podążać za błędami matki luteranki, ale za ojcem katolikiem - 12 kwietnia 1667 roku, jakiś chłopak w wieku 17 lat z przedmieścia Malborka z , heretyckich rodziców” 24 maja 1670 roku, Teodor Hartenius, akademik królewiecki, syn predykanta z Księstwa Pruskiego - 15 października 1670 rok.

\subsection{Skrucha i wyrzuty sumienia}

W 1666 roku Krzysztof Meske, stolarz, który za bluźnierstwo przeciwko Matce Boskiej miał przebity język ${ }^{89}$, po upływie roku wykazał skruchę, przechodząc na katolicyzm. Pewna służąca, apostata, która zawsze przeżywała katusze sumienia, powróciła na łono Kościoła w $1666 \mathrm{roku}^{90}$.

\footnotetext{
88 Naprawa błędów - odstąpienie od „błędnowierstwa”, od innej wiary niż katolicka.

89 To samo: AAWO, H. 11, Historia Residentiae Mariaburgensis, k. 14v.

90 To samo: AAWO, H. 11, Historia Residentiae Mariaburgensis, k. 15.
} 


\subsection{Wdarzenia cudowne i nadprzyrodzone}

W 1669 roku pewna niewidoma apostata, uczyniwszy uroczysty ślub przed obrazem Najświętszej Marii Panny Malborskiej, odzyskała wzrok, po czym ślubu dotrzymała i się nawróciła. 29 września 1677 roku, w święto Świętego Michała Archanioła Piotr Panser Nagel, będąc na wałach zamkowych, doznał nawrócenia, oglądając iluminowaną figurę Matki Boskiej na zewnątrz kościoła zamkowego Najświętszej Marii Panny. Niejaka Anna Kulpierzowa W skrajnie ciężkiej chorobie, upomniana we śnie, aby zostać katoliczką, posłuchała przestrogi. Podobnie Jan Tracz z przedmieścia, upomniany we śnie, posłuchał ostrzeżenia i został katolikiem (1665) ${ }^{91}$. W 1665 roku Anna Deptowna, panna z przedmieścia Malborka, opętana przez demona, odrzuciła herezję luterańską i posiadła wiarę katolicką, zaś zamężna Anna, kilkukrotnie kuszona i napastowana przez Szatana w nocy, uciekła do kościoła i tam została 22 grudnia 1670 uwolniona.

\subsection{Inne}

Poza okolicznościami przedstawionymi powyżej można też wymienić konwersje spowodowane przez inne czynniki. Np. Jan Everard Busma z Brunszwiku, akademik królewiecki, nawrócił się w 1670 roku na skutek wysłuchania kazań o. Marcina Radau (1616-1687) z Braniewa, wybitnego retora i wieloletniego misjonarza w Królewcu ${ }^{92}$. Obecność Busmy na liście świadczy, że do nawrócenia doszło najpewniej podczas wizyty w Malborku. Innym motywem nawrócenia były zależności osobiste na terenie zamku i parafii malborskiej. Dotyczyły one przede wszystkim pracującej tutaj służby urzedników, służby folwarcznej i rzemieślników z podzamcza. Krystyna, służąca wiceekonoma malborskiego Daniela Krawenberga, uległa konwersji w 1665 roku, w 1676 roku - ciężko chorujący Jakub, stary sługa i towarzysz broni ekonoma malborskiego Franciszka Bielińskiego, następnie Paweł, poddany burgrabiego i wójta malborskiego Samuela Zawadzkiego wraz z córką - w 1678 roku, Katarzyna, służąca tegoż urzędnika w 1679 roku. 20 listopada 1676 roku nawrócony został piwowar zamkowy Jan, który niebawem zmarł. Murarz zamkowy Dawid Spoth nawrócił się w lutym, a jego córka Dorota w listopadzie 1666 roku, ślusarz z przedzamcza Henryk Reinhold w 1666 roku, jego

91 To samo: AAWO, H. 11, Historia Residentiae Mariaburgensis, k. 14v.

92 Autor znanego w Europie podręcznika wymowy Orator extemporaneus (1655) - EWJ, s. 558. 
żona Katarzyna niecały rok później, zaś kolejna córka murarza zamkowego Katarzyna w 1674 roku.

Jezuici malborscy nawracali też służbę z folwarków zamkowych, jak chociażby Michała Birka z folwarku Kominki na Wielkich Żuławach Malborskich w 1667 roku czy Barbarę, córkę niejakiego Weissa z folwarku Piaski rok wcześniej. Konwersji ulegała też służba z majątków należących do rezydencji, jak Paweł, arendarz jezuicki z Nowego Stawu (1676) i Krystian, parobek jezuitów w Kościeleczkach (1677). Na koniec trzeba wspomnieć o konwertytach pracujących w malborskiej parafii, jak Andrzej, sługa oficjała pomezańskiego Bernarda Sassina (1667) czy muzyk z kościoła parafialnego o imieniu Krzysztof (1670).

\section{Nawracający: misjonarze, kaznodzieje, operariusze, spowiednicy}

Sposób prowadzenia misji został ogólnie ujęty w konstytucjach Towarzystwa Jezusowego. W XVIII wieku pojawiły się również pierwsze podręczniki dla misjonarzy jezuickich ${ }^{93}$. W tamtym czasie nie było jeszcze przy rezydencji malborskiej szkoły94 ${ }^{94}$ cała działalność rezydencji skupiała się więc na pracy duszpasterskiej i prowadzeniu wędrownych misji ludowych. Obszar, na którym operowali jezuici malborscy, był rozległy. Dotarcie na obszar Żuław było utrudnione lub często niemożliwe w okresach późnozimowych i wiosennych roztopów, corocznych zatorów lodowych na Nogacie oraz regularnego przerywania wałów przeciwpowodziowych przez wylewające wody tej rzeki oraz Wisły. Ze względu na kiepską jakość dróg nawet dotarcie na odleglejsze przedmieścia Malborka wymagało brodzenia w błocie ${ }^{95}$. W roku 1640 przebycie dystansu o długości 90-100km z Lubawy do Malborka, który dzisiaj można przejechać w nieco ponad godzinę, zajęło wizytatorom diece-

93 Zob. Archiwm Prowincji Polski Południowej Towarzystwa Jezusowego w Krakowie (ATJKr), sygn. 76, Podręcznik misjonarza; ATJKr, sygn. 86, Praxis missionis in pagis peragandae; ATJKr, sygn. 90, Praxis missionis ruralis peragendae in pagis Collegii Duneburgensis - L. Grzebień, Inwentarz Archiwum Prowincji Polski Poludniowej Towarzystwa Jezusowego w Krakowie. Rękopisy do 1820 roku, Kraków 2017, s. 36-38.

94 Pierwsi magistrowie pojawiają się w Malborku w latach 1677-1679, a więc pod koniec omawianego tutaj okresu, w roku 1678 notowany też jest pierwszy profesor, o. Sebastian Limanowicz. Świadczy to o uruchomieniu pierwszej szkoły jezuickiej w Malborku w roku szkolnym 1677/1678 - Cat. Trienn. 1678, k. 30v.-31; Cat. Brev. 1678/1679, k. 303-303v.

95 AAWO, H. 11, Historia Residentiae Mariaburgensis, k. 90v. 
zjalnym 2,5 dnia $^{96}$. Z powyższego wynika, że zależnie od obszaru misje poza obszarem miasta musiały trwać od kilku do kilkunastu dni lub nawet kilku tygodni ${ }^{97}$. Jezuici, zgodnie z konstytucjami zakonnymi, mogli się utrzymywać w razie konieczności z żebrania ${ }^{98}$. $Z$ wyżebranej jałmużny podczas misji żyli zakonnicy malborscy, o czym wspomina kronika rezydencji malborskiej ${ }^{99}$.

Na podstawie katalogów rocznych i trzyletnich udało się ustalić, że w latach 1662-1679 pracowało w Malborku 50 jezuitów - 39 ojców, 2 magistrów i 9 braci ${ }^{100}$. Przeciętnie w tym okresie rezydencja liczyła od 4 do 10 zakonników. Wyjątkowo liczna jak na Malbork była obsada w latach 1678 i 1679, kiedy to pracowało tutaj odpowiednio 9 i 10 jezuitów (tab. 11).

Tab. 11. Liczebność obsady malborskiej rezydencji jezuitów w latach 1662-1679

\begin{tabular}{|c|c|c|c|}
\hline Rok & Liczebność obsady & Rok & Liczebność obsady \\
\hline $1661 / 1662$ & 5 & $1670 / 1671$ & 6 \\
\hline $1662 / 1663$ & 4 & $1671 / 1672$ & 5 \\
\hline $1663 / 1664$ & 5 & $1672 / 1673$ & 5 \\
\hline $1664 / 1665$ & 5 & $1673 / 1674$ & 6 \\
\hline $1665 / 1666$ & 5 & $1674 / 1675$ & 6 \\
\hline $1666 / 1667$ & 6 & $1675 / 1676$ & 6 \\
\hline $1667 / 1668$ & 6 & $1676 / 1677$ & 6 \\
\hline $1668 / 1669$ & 6 & $1677 / 1678$ & 9 \\
\hline $1669 / 1670$ & 5 & $1678 / 1679$ & 10 \\
\hline
\end{tabular}

Źródło: ARSI, Pol. 43, 44, katalogi roczne; ARSI, Pol. 14-17, katalogi trzyletnie.

96 M. Józefczyk, Z dziejów religijnych Pomezanii w XVII wieku, t. 2, Malbork 2012, s. 277.

97 S. Kościelak, Jezuici w Gdańsku..., dz. cyt., s. 250-253.

$98[\ldots]$,i niech gotowi będą chodzić na żebranie od domu do domu, kiedy tego abo posłuszeństwo, abo potrzeba będzie wyciągała" - Reguty Societatis Iesu. Summaryusz abo krótkie zebranie tych ustaw, które należa ku duchownemu naszych wprawieniu: i od wszystkicha zachowane bydź maja, Sandomierz 1696, s. 13.

99 AAWO, H. 11, Historia Residentiae Mariaburgensis, k. 13v., 25v.

100 Cat. Brev. 1661/1662, k. 183; Cat. Brev. 1663/1664, k. 191v.; Cat. Brev. 1664/1665, FG. 1537/9/44, s. 10; Cat. Trienn.1665, k. 176; Cat. Brev. 1665/1666, k. 199, 208v.; Cat. Brev. 1666/1667, k. 218v.; Cat. Brev. 1667/1678, k. 228; Cat. Trienn. 1669, k. 34; Cat. Trienn. 1672, k. 158; Cat. Brev. 1672/1673, k. 12v.; Cat. Brev. 1674/1675, k. 261v.-262; Cat. Trienn. 1675, k. 35-35v.; Cat. Brev. 1675, k. 284v.; Cat. Brev. 1676, k. 295v.; Cat. Trienn. 1678, k. 30v.-31; Cat. Brev. 1678/1679, k. 303-303v. 
Schemat organizacyjny rezydencji malborskiej w omawianym okresie nie zmieniał się znacząco i można go przedstawić na przykładzie roku 1666/1667 ${ }^{101}$. Na jej czele stał wówczas superior o. Stanisław Kukliński, będący jednocześnie rezolutorem kazusów ${ }^{102}$. Także jego podwładni pełnili równocześnie kilka funkcji. Ojciec Franciszek Olędzki był operariuszem, misjonarzem, drugim spowiednikiem domu, konsultorem i rozgrzeszającym z herezji i schizmy, o. Jerzy Treug - kaznodzieją niemieckim, operariuszem, konsultorem i rozgrzeszającym z herezji i schizmy, o. Paweł Ćwielugowicz operariuszem i misjonarzem, o. Walenty Sophronius - ojcem duchownym, monitorem ${ }^{103}$, pierwszym spowiednikiem domu i kaznodzieją polskim, natomiast brat Szymon Kwiecki - socjuszem wychodzących i prokuratorem majątków rezydencji ${ }^{104}$. Jeżeli chodzi o stopnie zakonne, to ojcowie Kukliński i Treug byli profesami czterech ślubów, czyli jezuitami, którzy złożyli czwarty ślub posłuszeństwa papieżowi w sprawach misji ${ }^{105}$. Pozostali ojcowie byli koadiutorami duchownymi przygotowanymi przede wszystkim do spowiadania wiernych, głoszenia kazań i nauczania katechizmu ${ }^{106}$, zaś brat Kwiecki był koadiutorem doczesnym zajmującym się zarządzaniem rezydencją i jej

101 ARSI, Pol.44, Catalogus Brevis, Residentia Mariaeburgensis 1666, k. 218v.

102 Resolutor casuum - jezuita omawiający z ojcami spowiednikami różne przypadki sumienia. Funkcja występuje powszechnie w XVII-wiecznych katalogach rocznych. Resolutor casuum był odrębny od professor casuum, ponieważ w źródłach jezuickich pojawia się zapis: professor et resolutor casuum. Słowo ,rezolutor” funkcjonowało w XVII-wiecznej polszczyźnie jezuickiej - zob. T. Młodzianowski, Kazania i homilyie na niedziele doroczne, Poznań 1681, s. 351: Patrzcież Ewangelicznego Teologa, Kazisty, Rezolutora [...]. Zob. też: Stowniczek funkcji zakonnych, w: S. Kościelak, Skład osobowy kolegium gdańskiego oo. jezuitów (XVI-XVIII wiek), Gdańsk 2005, s. 168-174; EWJ, s. 881 podaje: „Resol. cas. - Resolutor casuum - kierujący omawianiem kazusów (przypadków) moralnych"; G. Łuszczak, Nauczyciele $i$ wychowawcy szkót jezuickich we Lwowie 1608-1773, Kraków 2010, s. 44: Resolutor Casuum et Controversiarumrozwiązuje kazusy i kontrowersje.

103 W polskich źródłach jezuickich z XVII wieku występuje wyłącznie monitor. J. Kołacz, Słownik języka i kultury jezuitów polskich, Kraków 2006, s. 46 podaje formę admonitor; EWJ, s. 880: „Mon. - Monitor (zob. admonitor)”.

104 Socius exeuntium - socjusz wychodzących, czyli brat koadiutor towarzyszący księżom w załatwianiu różnych spraw poza domem zakonnym.

105 Profesi (Professi) - księża, którzy złożyli trzy uroczyste śluby: ubóstwa, czystości i posłuszeństwa oraz czwarty ślub specjalnego posłuszeństwa ojcu świętemu w sprawach misji - EWJ, s. 539.

106 Koadiutorzy duchowni (Coadiutores spirituales) to księża o wykształceniu bardziej praktycznym, często po dwuletnim jedynie cyklu studiów teologicznych, przygotowani do spowiadania wiernych, głoszenia kazań, nauczania katechizmu, pełnienia funkcji prokuratorów itp. - EWJ, s. $286-287$. 
majątkiem ${ }^{107}$. Niezwykle ważna w kontekście omawianej w niniejszym artykule tematyki była funkcja rozgrzeszającego z herezji i schizmy (absoluet ab Haeresi et Schismate). Specjalnych uprawnień jezuitom w tym zakresie udzielał w imieniu Stolicy Apostolskiej miejscowy biskup, w tym przypadku hierarcha chełmiński i pomezański ${ }^{108}$.

Konstytucje zakonne regulowały szczegółowo sposób zachowania się kapłanów, wymieniając takie przymioty, jak miła aparycja oraz dobra kondycja fizyczna ${ }^{109}$. W XVII-wiecznym wydaniu konstytucji pouczano, że w obcowaniu z innymi należało zachowywać się spokojnie i z pokorą, bez okazywania niecierpliwości i pychy, wysławiać się skromnie, starannie dobierając słowa, spokojnym i cichym głosem. Nie należało wykonywać gwałtownych ruchów głową, ale raczej trzymać ją prosto, nie przechylać na żaden bok, a jedynie nieznacznie do przodu. Wzrok należało trzymać spuszczony, a podczas rozmowy, szczególnie z ważnymi osobami, patrzeć im nie w oczy, ale poniżej. Trzeba było unikać marszczenia brwi i nosa, ust nie zaciskać ani nie otwierać - twarz miała być spokojna - i okazywać raczej radość niż smutek. Ubiór miał być czysty i schludny. Ręce należało trzymać albo zajęte trzymaniem sukni albo spokojnie złożone. Chodzić należało z powagą, bez zbędnego pośpiechu, ustępować pierwszeństwa, swoim zachowaniem dając dobry przykład innym ${ }^{110}$. Całokształt wymienionych zasad i schematów zachowań stosowanych $\mathrm{w}$ praktyce misjonarskiej pomagał w realizacji postawionych sobie celów poprzez silne oddziaływanie na potencjalnych konwertytów. Do tego zestawu środków perswazji, mających na celu uniknięcie wywierania bezpośredniego nacisku na osobę nawracaną przez misjonarzy jezuickich, zaliczało się również urządzanie uroczystych procesji1111, przedstawień teatralnych ${ }^{112}$, prowadzenie dysput i polemik religijnych z innowier-

107 Koadiutorzy docześni (Coadiutores temporales) - bracia zakonni, spełniali obowiązki związane z administracją i obsługą domów zakonnych - EWJ, s. 286-287.

108 S. Kościelak, Jezuici w Gdańsku..., dz. cyt., s. 253, 267; A. Mariani, Duszpasterstwo jezuitów nieświeskich ..., dz. cyt., s. 65.

109 Konstytucje TJ, s. 90, 107-108, 221. Znaczenie wyglądu fizycznego dla powodzenia w pełnieniu posługi podkreślano np. w zamieszczonym w kronice rezydencji malborskiej wspomnieniu o zmarłym w 1667 roku ojcu Walentym Sofroniuszu, również doświadczonym i pracującym z pełnym poświęceniem misjonarzu - AAWO, H. 11, Historia Residentiae Mariaburgensis, k. 16-17.

110 Reguty Societatis Iesu 1696, s. 14-15, 35, 41-43.

111 Np. w Wielki Piątek 1671 roku w kościele parafialnym wystawiono Dialog, a w Boże Ciało tego samego roku odbyła się uroczysta procesja przez miasto - AAWO, H. 11, Historia Residentiae Mariaburgensis, k. 20-20v.

112 Np. w 1672 roku przedstawiono na scenie Chrystusa Umęczonego - AAWO, H. 11, Historia Residentiae Mariaburgensis, k. 21. 
cami, rozdawanie modlitewników, katechizmów, obrazków „świętych” nieumiejącemu czytać ludowi ${ }^{113}$, prowadzenie, czasami wielokrotnie, rozmów $\mathrm{z}$ wahającymi się $\mathrm{w}$ wierze lub osobami ocenionymi jako potencjalnie podatne na religijną argumentację ${ }^{114}$. Działania te powodowały, że niektórzy misjonarze zyskiwali szacunek wśród lokalnych społeczności. Np. pogrzeb zmarłego w 1667 roku misjonarza i kaznodziei Walentego Sophroniusa, który przepracował w Malborku 19 lat, zgromadzić miał tłumy żałobników, w tym miejscowych luteran, a wierni traktowali pozostałe po nim przedmioty niemal jak relikwie ${ }^{115}$.

Wśród jezuitów pracujących w omawianym okresie w Malborku było 15 misjonarzy, 17 uprawnionych do rozgrzeszania z herezji i schizmy, 23 operariuszy ${ }^{116}$ i kaznodziejów polskich oraz 8 operariuszy i kaznodziejów niemieckich (zob. tab. 12). Większość z nich pochodziła z różnych obszarów Rzeczypospolitej, jedynie kilku, przede wszystkim pełniących funkcje kaznodziejów niemieckich, z Prus Królewskich, Pomorza, Niemiec i Czech. Jak wspomniano, najczęściej pełnili oni po kilka funkcji jednocześnie. Ogół nawróceń przedstawionych w Series eorum był zasługą tych właśnie ludzi.

Tab. 12. Księża jezuiccy pracujący w Malborku w latach 1662-1679 117

\begin{tabular}{|c|c|c|c|}
\hline Misjonarze & $\begin{array}{c}\text { Rozgrzeszający } \\
\text { z herezji i schizmy }\end{array}$ & $\begin{array}{c}\text { Kaznodzieje } \\
\text { i operariusze polscy }\end{array}$ & $\begin{array}{c}\text { Kaznodzieje } \\
\text { i operariusze } \\
\text { niemieccy }\end{array}$ \\
\hline $\begin{array}{c}\text { Walenty Sophronius } \\
1661-1667\end{array}$ & $\begin{array}{c}\text { Jan Gasparides } \\
1660-1662\end{array}$ & $\begin{array}{c}\text { Walenty Sophronius } \\
1661-1667\end{array}$ & $\begin{array}{c}\text { Jan Gasparides } \\
1660-1662\end{array}$ \\
\hline $\begin{array}{c}\text { Stanisław Kukliński su- } \\
\text { perior 1663-1667 }\end{array}$ & $\begin{array}{c}\text { Andrzej Przygodzki } \\
\text { superior 1661-1663 }\end{array}$ & $\begin{array}{c}\text { Pawet Cwielugowicz } \\
1664-1665 \text { (kleryk, } \\
\text { pomocnik kaznodziei } \\
\text { polskiego) }\end{array}$ & $\begin{array}{c}\text { Krzysztof Bosuel } \\
1661-1663\end{array}$ \\
\hline
\end{tabular}

113 K. Drzymała, Praca jezuitów nad ludnościa wiejską w pierwszym stuleciu osiedlenia się zakonu w Rzeczypospolitej, „Nasza Przeszłość” t. 20 (1964), s. 60.

114 S. Kościelak, Konwertyci elbląscy, s. 185-186. Np. nad nawróceniem Jerzego Echlera w 1667 r. pracowano cierpliwie dwa lata - AAWO, H. 11, Historia Residentiae Mariaburgensis, k.15v.-16.

115 Dzieje malborskiej rezydencji..., dz. cyt., s. 40.

116 Operariusz (Operarius) - ksiądz spełniający obowiązki duszpasterskie, głównie głoszenia kazań i udzielania sakramentów świętych. Pracujących poza domem zakonnym nazywano też misjonarzami - EWJ, s. 475.

117 Na podstawie nieopublikowanych jeszcze badań prowadzonych w ramach rozprawy doktorskiej Jezuici w Malborku w XVII wieku udało się ustalić, że w latach 1618-1697 pracowało w rezydencji malborskiej aż 181 jezuitów. Dane zawarte w tabeli 13 pochodzą z biogramów jezuitów malborskich przygotowanych przez autora jako załącznik do wspomnianej dysertacji. 


\begin{tabular}{|c|c|c|c|}
\hline $\begin{array}{c}\text { Kazimierz Gałęski } \\
1665-1666\end{array}$ & $\begin{array}{c}\text { Krzysztof Bosuel } \\
1661-1663\end{array}$ & $\begin{array}{c}\text { Kazimierz Gałęski } \\
\text { 1665-1666 }\end{array}$ & $\begin{array}{l}\text { Jan Peceldus } \\
1662-1663\end{array}$ \\
\hline $\begin{array}{c}\text { Franciszek Olendzki } \\
\text { 1666-1667 }\end{array}$ & $\begin{array}{c}\text { Walenty Sophronius } \\
1661-1667\end{array}$ & $\begin{array}{c}\text { Paweł Cwielugowicz } \\
1666-1669\end{array}$ & Jan Pade 1663-1664 \\
\hline $\begin{array}{c}\text { Jan Maniecki 1667- } \\
1668\end{array}$ & Jan Pade 1663-1664 & $\begin{array}{c}\text { Franciszek Olendzki } \\
1666-1667\end{array}$ & $\begin{array}{l}\text { Jerzy Treug } \\
1664-1667\end{array}$ \\
\hline $\begin{array}{c}\text { Marcin Faszcewski } \\
1668-1669\end{array}$ & $\begin{array}{l}\text { Paweł Cwielugowicz } \\
\text { 1664-1665 (kleryk) }\end{array}$ & $\begin{array}{c}\text { Piotr Kociuski } \\
1667-1668 \text { (poranny) }\end{array}$ & $\begin{array}{l}\text { Jan Peceldus } \\
1667-1668\end{array}$ \\
\hline $\begin{array}{l}\text { Piotr Brzeziński } \\
1668-1669\end{array}$ & $\begin{array}{c}\text { Kazimierz Gałęski } \\
\text { 1665-1666 }\end{array}$ & $\begin{array}{c}\text { Jan Maniecki } \\
\text { 1667-1668 } \\
\text { (popołudniowy) }\end{array}$ & $\begin{array}{l}\text { Jerzy Treug } \\
1668-1673\end{array}$ \\
\hline $\begin{array}{c}\text { Mikołaj Garczyński } \\
\text { 1669-1675 } \\
(1669-1673 \\
\text { komendariusz } \\
\text { w Lichnowach) }{ }^{\mathrm{I}}\end{array}$ & $\begin{array}{c}\text { Paweł Cwielugowicz } \\
1666-1669\end{array}$ & $\begin{array}{l}\text { Jerzy Treug } \\
1668-1673\end{array}$ & $\begin{array}{c}\text { Eliasz Envaldus } \\
1673-1674\end{array}$ \\
\hline Kasper Solski 1670 & $\begin{array}{c}\text { Franciszek Olendzki } \\
1666-1667\end{array}$ & $\begin{array}{c}\text { Tomasz Dobrzycki } \\
1668-1669\end{array}$ & $\begin{array}{l}\text { Jan Peceldus } \\
1674-1676\end{array}$ \\
\hline $\begin{array}{l}\text { Jan Orłowski } \\
1670-1671 \\
\text { (6 miesięcy) }\end{array}$ & $\begin{array}{l}\text { Jan Peceldus } \\
1667-1668\end{array}$ & $\begin{array}{l}\text { Jan Molski } \\
1669-1670\end{array}$ & $\begin{array}{c}\text { Henryk Hulleweg } \\
\text { 1676-1678 }\end{array}$ \\
\hline $\begin{array}{c}\text { Jan Latyczewicz } \\
\text { 1675-1676 } \\
\text { (misjonarz ludowy, } \\
\text { socjusz prokuratora } \\
\text { majątków brata } \\
\text { Bartłomieja Fugata) }\end{array}$ & $\begin{array}{c}\text { Mikołaj Garczyński } \\
1668-1675\end{array}$ & $\begin{array}{c}\text { Paweł Maieranowski } \\
\text { 1670-1675 } \\
\text { (popołudniowy) }\end{array}$ & $\begin{array}{c}\text { Eliasz Envaldus } \\
1677-1678\end{array}$ \\
\hline $\begin{array}{c}\text { Wojciech Mierecki } \\
\text { 1676-1678 }\end{array}$ & $\begin{array}{c}\text { Paweł Maieranowski } \\
1670-1675\end{array}$ & $\begin{array}{c}\text { Ignacy Pierzcha } \\
1670-1671\end{array}$ & $\begin{array}{l}\text { Błażej Pataki } \\
1678-1679\end{array}$ \\
\hline $\begin{array}{c}\text { Eliasz Envaldus } \\
1677-1678\end{array}$ & $\begin{array}{c}\text { Jan Peceldus } \\
1674-1676\end{array}$ & $\begin{array}{c}\text { Jan Maniecki } \\
1671-1676 \\
\text { (popołudniowy) }\end{array}$ & \\
\hline $\begin{array}{l}\text { Błażej Pataki } \\
1678-1679\end{array}$ & $\begin{array}{l}\text { Piotr Kociuski } \\
1675-1676\end{array}$ & $\begin{array}{c}\text { Tomasz Kuczkowski } \\
1673-1674\end{array}$ & \\
\hline \multirow[t]{5}{*}{$\begin{array}{c}\text { Mikołaj Garczyński } \\
\text { 1679-1681 }\end{array}$} & $\begin{array}{c}\text { Jan Skrzyński } \\
1676-1678\end{array}$ & $\begin{array}{c}\text { Piotr Kociuski } \\
1675-1676 \text { (poranny) }\end{array}$ & \\
\hline & $\begin{array}{c}\text { Henryk Hulleweg } \\
\text { 1676-1678 }\end{array}$ & $\begin{array}{c}\text { Jan Skrzyński } \\
1676-1678\end{array}$ & \\
\hline & $\begin{array}{c}\text { Wojciech Mierecki } \\
1676-1678\end{array}$ & $\begin{array}{c}\text { Wojciech Mierecki } \\
\text { 1676-1678 } \\
\text { (popołudniowy) }\end{array}$ & \\
\hline & $\begin{array}{l}\text { Błażej Pataki } \\
1678-1679\end{array}$ & $\begin{array}{c}\text { Kazimierz Oczosalski } \\
\text { 1677-1678 } \\
\text { (6 miesięcy, kleryk) }\end{array}$ & \\
\hline & $\begin{array}{c}\text { Ignacy Pierzcha } \\
\text { 1679-1680 }\end{array}$ & $\begin{array}{c}\text { Jan Zdzański } \\
\text { 1677-1678 (kleryk) }\end{array}$ & \\
\hline
\end{tabular}




\begin{tabular}{|l|c|c|c|}
\hline & & Sebastian Limanowicz & \\
$1677-1678$ & \\
\hline & & Jan Długoborski & \\
& $1677-1678$ & \\
& & (6 miesięcy) & \\
\hline & & Juliusz Suley & \\
& & (popołudniowy, & \\
& kleryk) & $1678-1679$ & \\
\hline & & Ignacy Pierzcha & \\
& & $1679-1680$ & \\
\hline
\end{tabular}

I Komendariusz był to duchowny, który sprawował opiekę duszpasterską w czasie, gdy parafia wakowała, jak i wówczas gdy pleban nie rezydował przy powierzonej parafii.

Źródło: ARSI, Pol. 44, katalogi roczne; ARSI, Pol. 14-17, katalogi trzyletnie.

\section{Zakończenie}

Na skutek spustoszeń parafii i kościołów oraz ucieczki kleru świeckiego podczas II wojny szwedzkiej (1656-1660), po jej zakończeniu jezuici rezydencji malborskiej byli bardzo potrzebni do pełnienia posługi duszpasterskiej na obszarze oficjałatu pomezańskiego, a nawet nadgranicznego obszaru Prus Książęcych. Posługę podjęli niezwłocznie po zakończeniu działań wojennych w ekstremalnych warunkach bytowych. Pokój oliwski podpisano 3 maja, a już 21 maja dwóch jezuitów przybyło do Malborka. Przez najbliższe kilka miesięcy zmuszeni byli żyć z wyżebranej jałmużny. W tym czasie misjonarze i kaznodzieje wyruszali do opuszczonych parafii na Żuławach Malborskich i w Prusach Górnych.

W świetle danych uzyskanych z omawianego w artykule dokumentu ustalono, że konwersji na katolicyzm podlegały najczęściej osoby o niskim statusie społecznym, w różnym wieku, w tym ludzie młodzi, a nawet dzieci, osoby znajdujące się w trudnej sytuacji życiowej, z tego powodu prawdopodobnie bardziej podatne na stosowane przez jezuitów środki perswazji. Również osoby z nizin społecznych (służba, robotnicy rolni), rzadziej mieszczanie i szlachta. Wśród konwertytów było również wielu mieszkańców przedmieść, jezuitom trudniej było bowiem działać wewnątrz murów miejskich, gdzie spotykali się z dużą niechęcią luterańskiej większości. Zdecydowaną większość konwertytów stanowili wyznawcy Kościoła augsburskiego, wywodzący się 
z szerzej pojętego obszaru Malborka, na który w XVII wieku składały się: miasto i przedmieścia oraz zamek i podzamcze. Drugą pod względem liczebnym grupą nawróconych byli konwertyci pochodzący z Prus Książęcych. Nawracano ich albo w przygranicznych parafiach Prus Królewskich, albo już na terytorium samego księstwa. Oprócz nawróceń udzielano tam miejscowym sakramentów, do których nie mieli dostępu, i umacniano w wierze. Cały opisany ogrom pracy misjonarskiej wykonany został przez obsadę liczącą rocznie zaledwie od 4 do 10 jezuitów. Tak ciężkie warunki pełnienia posługi musiały szybko prowadzić do wyczerpania fizycznego, stąd zapewne duża rotacja składu osobowego. Średni okres pracy większości jezuitów w Malborku trwał zaledwie około 1 roku. Wysiłek ten spowodował, że pomimo znacznie skromniejszej liczby pracowników osiągnięcia jezuitów rezydencji malborskiej na polu konwersji na katolicyzm porównywalne są w Prusach Królewskich jedynie z wynikami kolegium w Gdańsku-Starych Szkotach.

Praca duszpasterska jezuitów w latach 1662-1679 nie spotkała się z aprobatą duchowieństwa świeckiego diecezji pomezańskiej, które składało skargi biskupa. Pretekstem był sposób pracy jezuitów, żyjących często podczas misji z żebrania, na co zezwalały konstytucje zakonne, potraktowany jako odbieranie dochodów miejscowym proboszczom ${ }^{118}$. W efekcie biskup chełmiński i pomezański Kazimierz Jan Opaliński (1639-1693) wydał w 1683 roku zakaz odbywania misji w diecezji bez jego wyraźnej zgody. Jezuici malborscy przyjęli to jako wyraz dezaprobaty dla swoich działań ${ }^{119}$.

118 Konstytucje zakonu nie pozwalały jezuitom na pobieranie opłat za udzielanie sakramentów Reguly Societatis Iesu 1696, s. 13-14; Konstytucje TJ, s. 48, 67.

119 AAWO, H. 11, Historia Residentiae Mariaburgensis, k. 25v. 


\section{Series eorum Qui Societatis Jesu opera ab Anno Salutis 1662 ad 1678 , Fidem Catholicam sunt amplexi in Polonia ${ }^{120}$.}

\section{Mariaeburgensis Residentia Anno D[omi]ni 1662}

Catharina $^{121}$ ancilla Zelwaldensis ${ }^{122}$ ex Ducatu ${ }^{123}$.

Matthias Branicki Schismaticus ${ }^{124}$ Ecclesiae reconciliatus.

Martinus Schultz Neuterchensis ${ }^{125}$.

Anna de Montki ${ }^{126}$ post 20 annos Apostasiae ${ }^{127}$ rediit ad Ecclesiam.

Anna Ancilla de Katzenos ${ }^{128}$.

Anna de Peterwaldt ${ }^{129}$ cum duabus filiabus.

Item duo alii conversi quorum nomina non sunt annotata.

Dorothea, qua apostatauerat, ad Ovile Christi rediit.

120 ARSI, Historiae Poloniae 1648-1671, Pol. 53, Series eorum Qui Societatis Jesu opera ab Anno Salutis 1662 ad 1678, Fidem Catholicam sunt amplexi in Polonia, Mariaeburgensis Residentia, k. $262 \mathrm{v} .-268 \mathrm{v}$.

121 Nazwiska w dzisiejszym rozumieniu tego terminu u mieszczan i chłopów upowszechniły się w XVII i XVIII wieku. Być może dlatego niektóre osoby niskiego stanu w prezentowanym wykazie nie miały nazwisk. Świadczyć o tym mogą chociażby wykazy mieszkańców Malborka, dzierżawców ekonomii malborskiej, takie jak Jerzy Raytar, Wilhelm Furman, Paweł Wrotny, Augustynka Kuśnierka - Źródła do dziejów ekonomii malborskiej, t. 4, s. 78-84.

122 Zelwald - Zalewo (dawn. Zełwałd, niem. Saalfeld) - miasto w województwie warmińskomazurskim, w powiecie iławskim, na terenie krainy historycznej Prusy Górne. Ówcześnie w Prusach Książęcych.

123 Ducatus Prussiae - Prusy Książęce.

124 Schismaticus - schizmatyk, członek Kościoła prawosławnego.

125 Nowy Staw (dawniej Nytych, niem. Neuteich) - miasto w województwie pomorskim, w powiecie malborskim, siedziba gminy miejsko-wiejskiej Nowy Staw, położone na Żuławach Wiślanych nad rzeką Świętą.

126 Mątki (Montki, niem. Montken) - osada w Polsce położona w województwie pomorskim, w powiecie kwidzyńskim, w gminie Ryjewo.

127 Apostazja - porzucenie wiary religijnej.

128 Kaczynos (niem. Katznase) - osada w województwie pomorskim, w powiecie malborskim, w gminie Stare Pole na obszarze Żuław Elbląskich. W omawianym okresie na obszarze ekonomii malborskiej.

129 Pietrzwałd (niem. Peterswalde) - wieś w województwie pomorskim, w powiecie sztumskim, w gminie Sztum. W omawianym okresie w starostwie sztumskim. 
Elisabeth ancilla ${ }^{130}$ ex insula Gedanensis ${ }^{131}$ Catholica facta.

Paulus Vir 46 Annorum Gardino Veniens ultro fidem amplexus.

Eodem tempore Dorothea puella Gusiavensis ${ }^{132}$.

Catharina Uxor Pauli Suburbani ${ }^{133}$ conversa 1. Maii.

Gregorius ex platea Subarcensi ${ }^{134}$. 27. Maii.

Graecus $^{135}$ quidam in vita periculo mysteria fidei edoctus et confessus.

19 Junii.

Dorothea Ratkowna Lichtenfeldensis ${ }^{136}$. 26. Julii.

Augustinus Reicherd annorum 50.

$\mathrm{G}[\mathrm{e}] \mathrm{n}[\mathrm{er}] \mathrm{osa}$ Domina $^{137}$ Sara Balinska postea Mariana Vocata ${ }^{138} 25$.

Sept[embris].

Domina $^{139}$ Anna Peltinova. Et alia quaedam cuius nomen non est notatum. Anna Christiburgensis ${ }^{140}$ ancilla ab Apostasia revocata.

130 Ancilla - służka, służąca.

131 Insula Gedanensis - Żuławy Gdańskie.

132 Miejscowość nieustalona.

133 Suburbanus, suburbana - osoba z przedmieścia Malborka. Przedmieścia rozciągały się na wschód i południe od miasta. Zamieszkiwała je ludność niemająca prawa miejskiego, o niższym statusie społecznym, w tym również katolicka i pochodzenia polskiego. Na przedmieściu wschodnim mieli też działkę i ogród jezuici malborscy - zob. R. Panfil, Pierwsi jezuici w Malborku jako reprezentanci multietnicznego spoleczeństwa Rzeczpospolitej Obojga Narodów, w: Stan badań nad wielokulturowym dziedzictwem dawnej Rzeczypospolitej, red. W. Walczak, K. Łopatecki, Białystok 2017, s. 266-267, il. 14.

134 Platea subarcensis - podzamcze. W XVII wieku zamieszkałe głównie przez rzemieślników zamkowych oraz drobnych kupców podlegających jurysdykcji ekonomów malborskich i posiadających odrębne przywileje królewskie - zob. S. Wilhelmi, Collectanea. Marienburg in schwerer Zeit: Aufzeichnungen eines preussischen Bürgermeisters zwischen 1696 und 1726, Frankfurt am Main 2006, s. 56-65; Trzy wieki w granicach Rzeczpospolitej. Zamek malborski od inkorporacji do rozbioru (1454-1772). Katalog wystawy, oprac. A. Dobry, Malbork 2014, s. $14-15$.

135 Graecus - wyznawca Wschodniego Kościoła Ortodoksyjnego, prawosławny.

136 Jasna (niem. Lichtenfelde/Lichterfelde) - wieś na pograniczu Powiśla i Żuław Elbląskich w województwie pomorskim, w powiecie sztumskim, w gminie Dzierzgoń.

137 Generosa Domina - szlachetnie urodzona.

138 Sara Balińska, szlachcianka, zapewne krewna Stanisława Balińskiego h. Przosna (159712.06.1671), wójta malborskiego - AAWO, H. 11, Historia Residentiae Mariaburgensis, k. 19v.; J. N. Bobrowicz, Herbarz polski Kaspra Niesieckiego, Lipsk 1859, t. 2, s. 54.

139 Domina - tutaj: gospodyni.

140 Dzierzgoń (dawniej Kiszporg/Kiszpork, niem. Christburg) - miasto w województwie pomorskim, w powiecie sztumskim. W XVII wieku Dzierzgoń był starostwem grodowym i siedzibą wojewody malborskiego. 


\section{Anno D[omi]ni 1663.}

Elisabeth ancilla Prabuto ${ }^{141}$ oriunda, et Alia eiusdem nominis de Villa Węgry ${ }^{142}$.

Item Ancilla quaedam Prabutensis ${ }^{143}$.

Nicolaus Apostata unius anni conversus 9. Augustii.

Nobilis quaedam foemina annis undecim Apostata rediit 10. Augustii.

Martinus quidam 6. circiter annos apostata 24. Novemb[ris].

\section{Anno D[omi]ni 1664.}

Matthias tympanista ${ }^{144}$ Lutheranis $^{145}$ Parentibus ortus. 6. Januarii. Georgius ab Lutherana haeresi conversus 20. Martii ${ }^{146}$. Anna quaedam, in Paschate quod erat 13. Aprilis ${ }^{147}$.

Andreas Juvenis ex Suecia ${ }^{148}$ reversus apostata 1 Junii, quidam in carcere conversus.

Elisabeth Lichnoviensis ${ }^{149}$ incola conversa 24. Augustii.

Christophorus Meils apostata resipuit.

Anna Gregorii uxor ex platea Subarcensi 1. Novemb[ris].

Elisabeth Meynowa Suburbana.

Barbara ancilla post Sesqui annum ab Apostasia reducta 31. Decemb[ris].

141 Prabuty (niem. Riesenburg) - miasto we wschodniej części województwa pomorskiego w powiecie kwidzyńskim. W XVII w. w Prusach Książęcych.

142 Węgry (niem. Wengern) - wieś w woj. pomorskim, w pow. sztumskim, w gminie Sztum.

143 Z Prabut.

144 Dobosz.

145 Luteranin - wyznawca Kościoła ewangelicko-augsburskiego. W Malborku luteranizm był obok katolicyzmu głównym wyznaniem.

146 Zapewne wspomniany w kronice rezydencji oraz annałach Jerzy Orlicz. Kronika określa go jako byłego kaznodzieję kalwińskiego, który spędził 30 lat na służbie „u pewnego księcia” (któregoś z Radziwiłłów birżańskich?), aby po śmierci protektora zostać kaznodzieją luterańskim. Będąc w podeszłym wieku i zapewne bez środków do życia, zgłosił się do jezuitów malborskich, wyrażając gotowość do przejścia na katolicyzm w zamian za wsparcie życia doczesnego AAWO, H. 11, Historia Residentiae Mariaburgensis, k. 13v.; ARSI, Pol. 53, Annuae Provinciae Polonae 1664, Residentia Mariaeburgensis, k. 145.

147 W roku 1664 Niedziela Wielkanocna przypadała 13 kwietnia.

148 Szwecja.

149 Lichnowy (niem. Gross Lichtenau) - wieś w województwie pomorskim, w powiecie malborskim, w gminie Lichnowy, na obszarze Wielkich Żuław Malborskich. 
Jacobus de Pawlowo Ducalis Prussiae ${ }^{150}$. Alter eiusdem Nominis Catholicus factus. 6. Decemb[ris].

Praeter praedictos tres alii sunt Mariaeburgi conversi quorum nomina non sunt annotata.

In Missionibus Vero Septem ex Lutherana Secta, S[anctae] Ecclesiae Catholicae sunt aggregate.

\section{Anno D[omi]ni 1665.}

Catharina quaedam Suburbana

Dorothea ex Ducali Prussia 18. Februarii.

Fridericus Vir ex Ducali Prussia 12. Maii.

Sophia de Oppenburg, deserta apostasia rediit 29. Maii.

Thomas puer ex Lutheranis natus factus Catholicus.

Item Joannes alius puer.

Joannes Złotkowski Sartor ${ }^{151}$ ex Ducatu, 19. Julii.

Catharina Ptaszkowa post 50 annos Apostasiae graviter infirma rediit ad Ecclesiam.

Joannes puer ex Ducali Prussia 4. Octobris.

Catharina Harasowa Suburbana.

Anna Kulpierzowa in ultima infirmitate monita per Somnium, ut Catholica fieret, obtemperavit admonitioni.

Georgius Bolt Capitaneus ${ }^{152}$ a Luthero pulcher transfuga.

Joannes Tracz Suburbanus monitus persomnium, paruit monitioni Catholicus factus.

Georgius Poręba Capitaneus militum.

Jacobus puer Mariaeburgi natus ex Lutheranis.

Alii Novem conversi quorum nomina non notavit Confessarius ${ }^{153}$.

150 Pawłowo - wieś w województwie pomorskim, w powiecie kwidzyńskim, w gminie Gardeja. Ówcześnie w Prusach Książęcych. O Pawłowskich h. własnego z Pawłowa w Prusach Książęcych, posiadających włości koło Szynwałdu wspomina Niesiecki - J. N. Bobrowicz, Herbarz polski Kaspra Niesieckiego, t. 7, Lipsk 1841, s. 262-263.

151 Krawiec.

152 Capitaneus militum - kapitan wojskowy.

153 W 1665 roku spowiednikiem rezydencji był o. Kazimierz Gałęski. 
Abraham Paterson Mennonista ${ }^{154}$ iuvenis baptismum Suscepit de manu Concionatoris Germanici ${ }^{155}$.

Anna Deptowna Virgo Suburbana Daemoniis obsessa haeresim Lutheranam rejecit et fidem Catholicam assumpsit.

Carolus Homeltan Calvinista ${ }^{156}$ Capitaneus militum.

Joannes Jacob miles gregarius ${ }^{157}$ ex Ducatu.

Michael Prenger Elbingensis miles Sartor.

Georgius Romel Vir laboriosus ex Ducatu.

Philippus Reger miles Sierzant Brosvicensis ${ }^{158}$

Regina Coniunx Regeri Varsaviae nata, in Sueciam ab hostibus abducta una cum Viro Ecclesiae nomen dedit.

Michael Furman miles Gregarius.

Bartholomaeus arte Sutor.

Jacob Culmensis ${ }^{159}$ Fenestrarius per 10 annos in gratiam Uxoris Lutheranos factus, rediit ad Ecclesiam ${ }^{160}$.

Adolphus Kahl ex mercator Lubecensis 7. Decembris.

Dorothea Hoppin ancilla 13. Decemb[ris].

Andreas Kos de Bystrzec ${ }^{161}$ ex Voto 26. Decemb[ris].

Ancilla quaedam Tichnoviis ${ }^{162}$ eodem die facta Catholica.

Cristina famula Generosi D[omi]ni Viceaeconomi ${ }^{163} 31$. Decemb[ris].

154 To samo AAWO, H. 11, Historia Residentiae Mariaburgensis, k. 13v. Mennonici - wyznanie chrześcijańskie zaliczane do protestantyzmu, jest jednym z nurtów anabaptyzmu. U mennonitów chrztu udziela się młodzieży od 14 roku życia, zatem ochrzczony przez jezuitów Abraham Paterson był zapewne poniżej tego wieku.

155 Nawrócony przez kaznodzieję niemieckiego. W roku 1665 kaznodzieją niemieckim był o. Jerzy Treug.

156 Kalwinista - wyznawca kościoła ewangelicko-reformowanego.

157 Miles gregarius - szeregowy.

158 Brunsvicensis? - żołnierz pochodzący z Brunszwiku?

159 Chełmno (niem. Culm, Kulm) - miasto w województwie kujawsko-pomorskim.

160 To samo AAWO, H. 11, Historia Residentiae Mariaburgensis, k. 14v.

161 Biały Dwór (Bystrzec) - część wsi Brachlewo w województwie pomorskim, w powiecie kwidzyńskim, w gminie Kwidzyn. Andrzej Kos herbu własnego.

162 Tychnowy (niem. Tiefenau) - wieś w województwie pomorskim, w powiecie kwidzyńskim, w gminie Kwidzyn.

163 Służąca Daniela Floriana Krauenberga (Krawenberga), sekretarza królewskiego i wiceekonoma malborskiego. Na własny koszt gruntownie wyremontował w latach 1668-1669 położony na Zamku Niskim kościół św. Wawrzyńca, zniszczony przez Szwedów w czasie potopu M. Józefczyk, Z dziejów religijnych Pomezanii w XVII wieku, t. 1, dz. cyt., s. 132. 
Praeter praedictos Mariaeburgi convertos Septem alii in Pagis, opera Patris Missionariii ${ }^{164}$ orthodoxam fidem suscepere ${ }^{165}$.

\section{Anno D[omi]ni 1666.}

Catharina Bartkowa 16. Januarii.

Valentinus Urbanski miles 20. Januarii.

Christophorus Jordan miles ex Ducali 29. Januarii.

Gertrudis Radzikowska incola arcensis 30. Januarii.

David Spoth ${ }^{166}$ Murarius arcensis 16. Februarii.

Elisabeth z Rakowca ${ }^{167}$ ex Ducatus 17. Aprilis.

Gertrudis Petersche z Heybud ${ }^{168} 15$. Aprilis.

Marianna filia Fabri cuiusdam

Albertus Laszta ex Majori Polonia ${ }^{169}$.

Christianus Mertens gregarius miles 20. Aprilis.

Michael Skoczek laboriosus de Montowi ${ }^{170} 24$. Aprilis.

Elisabeth mulier 15. Maii.

Paulus Stencelino juvenis Pucensis ${ }^{171}$ 17. Maii.

Michael Puer Pentecoste ${ }^{172}$.

Elia Szukowa Mariaeburgensis 29. Maii.

Anna Lessetin 2. Junii

Andreas Taub murarius adolescens 11. Junii.

Georgius Herman Colonus ${ }^{173}$ in Damerau ${ }^{174}$ majorii Insula 30. Junii.

164 W 1665 roku misjonarzami byli superior rezydencji malborskiej o. Stanisław Kukliński i o. Kazimierz Gałęski.

165 To samo AAWO, H. 11, Historia Residentiae Mariaburgensis, k. 14v.

166 Tegoż córka Dorota nawrócona 5 listopada - zob. poniżej.

167 Rakowiec (niem. Gross Krebs) - wieś w województwie pomorskim, w powiecie kwidzyńskim, w gminie Kwidzyn.

168 Stogi Malborskie (dawniej Hejbudy oraz Heybudy, niem. Heubuden) - wieś w województwie pomorskim, w powiecie malborskim, w gminie Malbork na obszarze Wielkich Żuław Malborskich.

169 Z Wielkopolski.

170 Mątowy Wielkie (niem. Gross Montau) - wieś w województwie pomorskim, w powiecie malborskim, w gminie Miłoradz na obszarze Wielkich Żuław Malborskich.

171 Z Pucka. Puck (kaszub. Pùck lub Pùckò, niem. Putzig) - miasto w województwie pomorskim, leży na Kaszubach u ujścia rzeki Płutnicy do Zatoki Puckiej.

172 Pentecoste - Zesłanie Ducha Świętego, Pięćdziesiątnica, potocznie Zielone Świątki.

173 Kolonista, osadnik, dzierżawca gruntu, rataj, ubogi chłop.

174 Dąbrowa (niem. Damerau) - wieś w województwie pomorskim, w powiecie malborskim, w gminie Lichnowy na obszarze Wielkich Żuław Malborskich. 
Barbara Filia Weisz z Piasku' ${ }^{175} 11$. Julii.

Henricus Reinhold serifaber ${ }^{176}$ Subarcensis 13. Jul[ii].

Catharina puella Apostata 21. Julii.

Petrus Wolfgangus a Dorff Bohemus ${ }^{177}$ miles 30. Jul[ii].

Maria Gunterin 13 Aug[ustii].

Catharina ancilla 18. Augustii.

Barbara Anna Brettersche Porucznikowa 4. Septemb[ris].

Christina ancilla in Nowowies ${ }^{178}$ 6. Septemb[ris].

Christophorus Meske lignifaber, cui ob blasphaemiam in Virginem

Beatissimam transfossa erat lingua, postannum paenituit. 11.

Septemb[ris $]^{179}$.

Peter Werner Colonus in Fiszewie Insula minore ${ }^{180}$ 19. Septemb[ris].

Anastasia Ancilla 20. Octobris.

Dorothea filia Spoth $^{181}$. 5. Novemb[ris].

Marianna Strenczowna 9. Novembris.

Praeter nominatos plures alii sunt conversi in Missionibus ${ }^{182}$.

\section{Anno D[omi]ni 1667.}

Georgius Echler ${ }^{183}$ sutor, circa quem duobus laboratum annis, tandem ex Concione Controversistica; rediens domum Uxori dixit, terribilis fuit

175 Folwark zamkowy Piaski wchodzący w skład ekonomii malborskiej-zob. Źródta do dziejów ekonomii malborskiej, t. 4, dz. cyt., s. 73-74.

176 Ślusarz. Najpewniej identyczny z Henrikiem Reinholdem, który na podstawie kontraktu z ekonomem malborskim płacił czynsz z domku w Kałdowie w 1675 roku - zob. Źródła do dziejów ekonomii malborskiej, t. 4, dz. cyt., s. 82.

177 Bohemus - Czech.

178 Nowa Wieś Malborska - wieś w województwie pomorskim, w powiecie malborskim, w gminie Malbork. Część miejscowości znajduje się obecnie w granicach administracyjnych miasta Malborka i stanowi jego dzielnicę. Druga część znajduje się w granicach administracyjnych Gminy Malbork.

179 Przypadek luterańskiego bluźniercy o imieniu Krzysztof opisany w kronice rezydencji malborskiej pod rokiem 1665 - AAWO, H. 11, Historia Residentiae Mariaburgensis, k. 14v.-15, 16v.-17.

180 Fiszewo (niem. Fischau) - wieś w Polsce położona w województwie warmińsko-mazurskim, w powiecie elbląskim, w gminie Gronowo Elbląskie, na obszarze Żuław Elbląskich. Tutaj rzekomo na Małych Żuławach Malborskich.

181 Córka murarza zamkowego Dawida Spotha, nawróconego 16 lutego (zob. wyżej).

182 W roku 1666 jako misjonarze pracowali oo. Stanisław Kukliński, Kazimierz Gałęski i Franciszek Olendzki.

183 Osoba potwierdzona przez kronikę rezydencji malborskiej-AAWO, H. 11, Historia Residentiae Mariaburgensis, k. 15v.-16. 
concio, non posse Salvari nisi in una fidesi non iurassem in Lutheranismo, fierem Catholicus, deiectus hac opinione dedit manus. 23. Febr[uarii]. Andreas sartor in Nowowies ${ }^{184}, 15$. Martii, annorum 67, in ultima infirmitate conversus.

Christianus Schultz Holender ${ }^{185}$ ex Heybudi cum uxore Sua Gertrude 18. Martii.

Anna Catharina vidua ex Ducatu 19. Martii.

Hans Senka Wozny ${ }^{186}$ in ultima infirmitate. Cujus exemplum ultro Secuta uxor ejus Barbara 22. Martii.

Michael Müller ex Ducatu 26. Martii.

Christianus Janing Caupo ${ }^{187}$ 9. Aprilis Sabbato Sancto.

Quadam Apostata ob inopiam Sacredotis, postea per multos annos nullibi confessa, quia displicuit haeresis, et ex altera parte deterrita a Catholicismo, Specie peccati quod non liceat tertio mutare fidem. 10. Aprilis.

Andreas Famulus Perillus[tris] et A[dmodum] R[everendus] D[ominus] Officialis ${ }^{188} 11$. Aprilis.

Barbara Vidua ex Voldin ${ }^{189}$ in gravi infirmitate 12. Aprilis.

Anna puella noluit Seqvi errorem Parentum 13. Aprilis.

Famulus quidam Joannes in infirmitate Conversus 19. Aprilis.

Marianna puella 13 Annorum noluit Seqvi Matrem Lutheranam Sed potius Patres Catholicum 12. Aprilis.

Anna vidua post longam apostasiam 12. Aprilis.

Martinus adolescens ex Ducatu 23. Aprilis.

Quaedam Ruthena ${ }^{190}$ Schismatica 24. Aprilis.

Georgius Wisteney Sutor ${ }^{191}$ Senex 29. April[is].

Catharina vidua 11. Maii.

184 Nowa Wieś Malborska.

185 Olędrzy - osadnicy z Niderlandów, głównie mennonici, którzy w XVI, XVII i XVIII wieku zakładali wsie na Żuławach Gdańskich, Malborskich i Elbląskich w Prusach Królewskich.

186 Woźny.

187 Handlarz, karczmarz.

188 Sługa oficjała pomezańskiego i proboszcza malborskiego (1666-1673) Bernarda Sassina (zm. 1680) - biogram w: W. Zawadzki, Duchowieństwo katolickie oficjałatu pomezańskiego w latach 1525-1821, t. 2, Słownik, Elbląg 2009, s. 218. Zob. też M. Józefczyk, Z dziejów religijnych Pomezanii w XVII wieku, t. 1, dz. cyt., s. 119.

189 Miejscowość niezidentyfikowana.

190 Rusinka, kobieta wyznania prawosławnego z południowo-wschodnich rubieży Rzeczpospolitej.

191 Szewc. 
Michael Birk ex Kitminki Insula majoris ${ }^{192}$ 30. Maii.

Joannes Laboriosus ${ }^{193}$ 9. Junii.

Catharina uxor Henrici Reinhold ante annum Conversi ${ }^{194}$ 15. Junii.

Israel Sprengel Colonus ex Lichnowo majoris Insulae ${ }^{195}$.

Quaedam Ruthena Schisma abiecit.

Plures Sunt S[ancti] Matri Ecclesiae aggregati non annotati.

\section{Anno D[omi]ni 1668.}

Schismatica quaedam est reconciliata Ecclesiae 23. Septemb[ris].

Domina Dorothea Polakowska ${ }^{196}$ in extremis 3. Octob[ris].

Bartholomaeus Laboriosus 14. Octob[ris].

Andreas Corioth Civis Christiburgensis ${ }^{197}$ 17. Octob[ris].

Thomas Molings Calvinista Anglus Civis Stumen ${ }^{198}$ 4. Novemb[ris].

Matthias miles ex Ducali Prussia 18. Novemb[ris].

Quidam rediit ad Ecclesiam 8. Decemb[ris].

Item quidam Schismaticus 25. Dcemb[ris].

Domina Anna Regenborgin filia Civis Mariaeburg[ensis], Clavicularii uxor, nunc Wilhelmi Leutenantii 25. Decemb[ris].

Lutherani non sunt annotati triginta tres et Schismatici Viginti quatuor.

\section{Anno D[omi]ni 1669.}

Martinus Burski adolescens nobilis ${ }^{199}$ 5. Januarii.

Catharina pridie Nuptiarum 6. Januar[ii].

192 Kamionka (dawn. Kominki, niem. Kaminke) - powinno być: Kominki. Obecnie wieś w województwie pomorskim, w powiecie malborskim, w gminie Malbork na obszarze Wielkich Żuław Malborskich. W XVII w. Kominki, folwark zamkowy wchodzący w skład ekonomii malborskiej - zob. Źródła do dziejów ekonomii malborskiej, t. 4, dz. cyt., s. 72-73.

193 Pracowity - chłop.

194 Córka Henryka Reinholda, ślusarza z przedzamcza, nawróconego 13 lipca 1666 roku (zob. wyżej).

195 Lichnowy (niem. Gross Lichtenau) - wieś w województwie pomorskim, w powiecie malborskim na obszarze Wielkich Żuław Malborskich.

196 Jakub Polakowski nazywał się dzierżawca domku w Kałdowie w 1675 roku - zob. Źródła do dziejów ekonomii malborskiej, t. 4, dz. cyt., s. 79, 82.

197 Mieszczanin dzierzgoński.

198 Kalwinista, Anglik, mieszczanin sztumski. Sztum (niem. Stuhm) - miasto w województwie pomorskim, $15 \mathrm{~km}$ na południe od Malborka. W XVII wieku zamek sztumski był siedzibą starosty grodowego, a w kościele św. Anny odbywały się sejmiki województwa malborskiego.

199 Szlachcic Marcin Burski. 
Andreas puer 2. Febr[uarii].

Joannes Schismaticus 17. Februar[ii].

Martinus Schismaticus 7. April[is].

Joannes Laboriosus Svecus 13. April[is].

Regina Polakowska ${ }^{200}$ Subarcensis 17. Apr[ilis].

Christophorus Lietke miles ex Ducali Prussia 18. April[is].

Domina Esther G[e]no[ro]si D[omi]ni Weger coniunx Sabbatus S[anctus $]^{201}$

Martinus Klein miles ex Ducatu 29. April[is].

Anna Sculteti ex Fischau minoris Insulae filia ${ }^{202} 7$ Maii.

Michael Murarius ex Ducali Lithuania ${ }^{203}$ 29. Junii.

Catharina ancilla 2. Julii.

Barbara ancilla 8. Septembris.

Helena ancilla 6. Octobr[is].

Marianna ex Ducali Prussia 16. Novembris.

Catharina ancilla ante nuptias 23. Novembris.

Anna eius soror itidem Sponsa eadem die.

Schismaticus quidam in Nativit[as] D[omi]ni.

Quaedam Apostata nunquam quieta, rediit 29. Decembris

Viginti Octo Lutherani et Calvinistae quorum nomina non sunt annotata et Triginta Septem Schismatici

Septem Apostatae quarum una caeca facto voto ad B[eatissimae] V[irginis] Mariaeburgensis ${ }^{204}$ visum recepit votum impleuit et conversa est ${ }^{205}$.

\section{Anno D[omi]ni 1670.}

Joannes Bering miles oriundus ex Ducali Prussia 24. Februar[ii]. Anna ex Lithuania ${ }^{206}$ oriunda 25. Martii.

Dorothea Uxor Libratoris tormentorum 28. Martii.

Textor $^{207}$ oriundus ex Ducali Prussia, feria quinta magna cum Uxore conversus.

\footnotetext{
200 Krewna nawróconej rok wcześniej Doroty Polakowskiej?

201 W 1669 roku Wielka Sobota przypadała 20 kwietnia.

202 Córka sołtysa z Fiszewa.

203 Murarz z Wielkiego Księstwa Litewskiego.

204 Cudowny obraz Matki Boskiej Malborskiej.

205 To samo AAWO, H. 11, Historia Residentiae Mariaburgensis, k. 18v.

206 Tzn. z Wielkiego Księstwa Litewskiego.

207 Tkacz.
} 
Elisabeth ex Willenberg ${ }^{208} 3$. April[is].

Georgius Suburbanus Viduus Sabbato S[ancto] ${ }^{209}$

Christophorus Musicus Ecclesiae Parochialis ${ }^{210}$ 19. April[is].

Puer 17 annorum Suburbanus ex haereticis parentibus 24. Maii.

Jurek Parobek ex Ducali Prussiae 1. Junii.

Jan Schismaticus 8. Junii.

Ancilla quaedam apostata Semper habuit remorsum conscientiae, tandem resipuit 15. Junii.

Christianus Musicus Mariaeburgi 2. Julii.

Marianna Neuteychensis in gratiam mariti 19. Julii.

Joannes Everardus Busma Academicus Regimontanus ${ }^{211}$ ex Concionibus Patris Radau ${ }^{212}$ natione Bruswicensis ${ }^{213}$ 2. Aug[ustii].

Sophia Magdalena Pomerana quae marito converso in extrema infirmitate gn. miserat Catholicismum 9. Augusti[i].

Hieronymus Austin Pruthenus studiosus ${ }^{214}$ ex Voto in infirmitate concepto 6. Sept[embris].

Joannes Georgius Thoms chirotecarius ${ }^{215}$ 7. Septemb[ris].

Anna maritata ex Ducali Prussia 8. Septemb[ris].

Theodorus Hartenius Academicus Regimontanus ${ }^{216}$ filius predicantis ex Ducali Prussia 15. Octobris.

Mulier quaedam honeste Vestita in Conclusione Jubilaei post lapsum conversa ut consequeretur remissionem peccatorum 22. Octobris.

Christophorus laboriosus Christiburgensis 2. Novemb[ris].

Joannes Roth Calvinista ex Voto ad B[eatissimae]V[irginis]Turoviensis ${ }^{217}$ in gravi infirmitate facto. 19. Decembris.

Anna quadam maritata, a Sathana tentata, et de nocte aliquoties pressa, confugit ad Ecclesiam, et ita liberata est. 22. Decemb[ris].

208 Wielbark (niem. Willenberg) - obecnie południowa część Malborka, w XVII wieku odrębna miejscowość leżąca w starostwie sztumskim.

209 W 1670 roku Wielka Sobota przypadała 5 kwietnia.

210 Muzyk w kościele parafialnym św. Jana w Malborku.

211 Akademik z Uniwersytetu Albrechta w Królewcu (Albertyny).

212 O. Marcin Radau z kolegium w Braniewie.

213 Tzn. Brunsvicensis - z Brunszwiku.

214 Student.

215 Rękawicznik.

216 Akademik z Uniwersytetu Albrechta w Królewcu (Albertyny), syn predykanta z Prus Książęcych.

217 Turowo - wieś w województwie warmińsko-mazurskim, w powiecie nidzickim, w gminie Kozłowo. Biskup chełmiński Kazimierz Jan z Bnina Opaliński (1639-1693) w dobrach odkupionych od księcia pruskiego ufundował i uposażył kościół. 
Andreas laboriosus ab uxore sua inductus 26. Decemb[ris].

In missionibus ${ }^{218}$ etiam aliquot Ecclesiae Sunt Aggregati.

\section{Anno D[omi]ni 1671.}

Apostata quaedam rediit ad gremium Ecclesiae inducta a Sponso. 1 Jan[uarii].

Elisabeth itidem a Sponso inducta, cum consensu Haeretici parentis 6 Jan[uarii].

Barbara ancilla in extrema infirmitate deserta a suis, deseruit Sectam. 15. Jan[uarii].

Hedvigis Maritata in infirmitate 19. Martii.

Dorothea ancilla ex Ducali Prussia et Anna Maritata. 29. Martii.

Barbara ex Starogart ${ }^{219}$ oriunda 8. April.

Duo Coniuges conversi quorum unus stimulabatur Semper ad fidem.

Dorothea ancilla 24. Maii.

Christophorus Kura suburbanus Sexagenarius in infirmitate 30. Julii.

Marianna ancilla 4. Octobris.

Joannes laboriosus ex Voto infirmitate ex Ducali Prussia 8. Novembr[is]. Thomas puer Mariaeburgensis 22. Novembris.

Anna quaedam pauper ab aliquot annis non erat confessa apud suos, dicens, non habeo quod dem pro confessione quam apud Catholicos gratis habere possum. 25. Novemb[ris $]^{220}$.

\section{Anno D[omi]ni 1672.}

Catharina puella Mariaeburgensis 30. Januarii.

Anna Maritata 9. Februar[ii].

Catharina Suburbana 24. Martii.

Ancilla ex Ducali Prussia accepta facultate a Parente haeretico 10. April[is].

Fridericus Fittloff Laux Porucznik 13. April[is].

Balthasar Laboriosus ex Ducali Prussia 17. April[is].

Catharina Frezerin ex Scotia Calvinismum deservie Kapitanowa ${ }^{221}$

218 Misjonarzami w roku 1671 byli oo. Mikołaj Garczyński i Jan Orłowski.

219 Obecnie Starogard Gdański - miasto w województwie pomorskim, jedno z najstarszych miast na Pomorzu.

220 To samo AAWO, H. 11, Historia Residentiae Mariaburgensis, k. 20-21v., ale pod rokiem 1672.

221 Żona kapitana, zapewne najemnej piechoty szkockiej o nazwisku Frazer. 
Georgius miles in ultima infirmitate 6. Junii.

Fridericus Arcularius 222 oriundus Coneco ${ }^{223}$ juvenis 6. Junii.

Quidam Sartor cum Uxore 13. Junii.

Hans Schmit Laboriosus 2. Julii.

Catharina Suburbana oriunda ex Pomerania ${ }^{224}$ cum filio 11 annorum.

Joannes Laboriosus ex Ducali Prussiae 18. Septembr[is].

Catharina ex Ducali Prussia inducta a Sponso 21. Septemb[ris].

Regina Kapralowa ex Ducali Prussia 15. Octob[ris].

Georgius miles ex proposito facto in bello Moschovitico 225 27. Octob[ris].

Catharina inducta a Sponso in Münsterberg ${ }^{226}$.

Anna 10. Novembris.

Quidam Colonus insulanus Wegner, occulti 1. Decemb[ris].

\section{Anno D[omi]ni 1673.}

Christianus Faber 30. Januarii

Maria Ancilla Prutena 2. Februarii

Jacobus Regis 6. Februarii

Anna militis arcensis Consors cum Marito

Elisabeth a fide apostata 20 fere annos 22. Octob[ris].

Laboriosus Sulaviensis ${ }^{227}$ ad fidem conversus.

Quaedam titubans in fide ob sacrilege factam primam conversionis confessionem ad integram confessionem faciendam in ducta et in fide firmata.

Anna maritata ab Haeresi absoluta 29. Octob[ris].

Quaedam in primam conversione ad fidem Catholicam, Sacrilege confessa, concione ad monita confessionem integram fecit, $[\ldots]^{228}$

Alia $[\ldots]^{229}$ post Confessiones multorum annorum Sacrilege factas integre confessa.

222 Cieśla, stolarz.

223 Pochodzący z Chojnic. Chojnice (niem. Konitz) - miasto w województwie pomorskim, siedziba rezydencji jezuitów.

224 Pochodząca z Pomorza mieszkanka przedmieść malborskich.

225 Wojna polsko-rosyjska (1654-1667).

226 Stara Kościelnica (niem. Altmünsterberg) - wieś w województwie pomorskim, w powiecie malborskim, w gminie Miłoradz na obszarze Wielkich Żuław Malborskich.

227 Z Żuław.

228 Fragment tekstu celowo wytarty i nieczytelny.

229 Duży odstęp. 
Susanna conversa Laborioso cuidam copulanda.

Elisabeth 3. Decembrii

Georgius Nather Civis ${ }^{230}$ 3. Decemb[ris].

Joannes Klas miles 21. Decemb[ris]. Eiusdem sponsa vidua Anna.

Eva Fabri Ferrarii uxor ${ }^{231}$ post pontem.

\section{Anno D[omi]ni 1674.}

David Berent figulus 232 7. Januarii. Michael eiusdem filius uxoratus.

Catharina Vilhelmi Vectoris Uxor ${ }^{233}$ 14. Jan[uarii].

Joannes Zakobielski²34 21. Januarii.

Michael miles arcensis, faber lignarius ${ }^{235} 30$. Januarii

Jacobus Colonus Zulaviensis 31. Januarii.

Catharina filia Murariae in arce ${ }^{236} 27$. Februarii.

Catharina Senicula ${ }^{237}$ apud Georgium Schultz eodem die ${ }^{238}$.

Joannes Darhoff miles brandeburg[ensis]. 18. Martii.

Christophorus Groth murarius ${ }^{239}$ uxoratus.

Jacobus Reis laboriosus germanus 25. Martii.

Fabianus sartor adolescens 30. Martii.

Barbara Georgii Mansfelt militis uxor quae antea habuit praedicantem maritum. 28. Aprilis.

Catharina ancilla in Kozliczki²40 13. Maii.

230 Zapewne mieszczanin malborski.

231 Żona kowala.

232 Garncarz.

233 Katarzyna żona woźnicy Wilhelma lub woźnicy o nazwisku Wilhelmi, które występowało w Malborku w XVII i XVIII wieku, ale wśród ewangelickiego patrycjatu miasta. Rodzina wywodziła się z Tczewa - zob. S. Wilhelmi, Collectanea. Marienburg in schwerer Zeit: Aufzeichnungen eines preussischen Bürgermeisters zwischen 1696 und 1726, dz. cyt., s. 1422. Z kolei furman o imieniu Wilhelm wspomniany jest jako płacący ekonomii malborskiej czynsz z domku między bramami i ogrodu przy cegielni w 1675 roku - zob. Źródta do dziejów ekonomii malborskiej, t. 4, dz. cyt., s. 80, 83.

234 Lub Zakobielski.

235 Cieśla.

236 Córka murarza zamkowego.

237 Starucha.

23827 lutego.

239 Murarz.

240 Kościeleczki (dawniej Koźliczki, niem. Warnau) - wieś w Polsce położona w województwie pomorskim, w powiecie malborskim, w gminie Malbork na obszarze Wielkich Żuław Malborskich. Kościół i parafia w Kościeleczkach przekazane zostały na uposażenie rezydencji malborskiej 
Gertrudis maritata in Piaski 14. Maii.

Catharina ancilla ex praedio Caldovo ${ }^{241} 24$. Junii.

Georgius Heling Neiteichensis ${ }^{242}$ 6. Julii.

Marianna Domina Poremba in Nova Villa ${ }^{243}$

Catharina a Schismate.

Constantinus absolutus a Schismate in Sept[embris].

Anna in Ducatu perversa, rursum conversa 12. Sept[embris].

Barbara ex Kozliczki 2. Octob[ris].

Catharina Uxor Catholici 18. Novemb[ris].

Jacobus maritus Catholicae 21. Novemb[ris].

Jacobus et Marianna Neo sponsi 30. Novemb[ris].

Uxor cuiusdam Lutherani 23. Decemb[ris].

Catharina Fischerin Uxor ${ }^{244}$ Haderi 24. Decemb[ris].

\section{Anno D[omi]ni 1675.}

Catharina Vidua ex Polschau ${ }^{245}$ 8. Januarii.

Anna Vidua apostata ab annis 20, 20. Januarii.

Dorothea Hermanin nupta Catholico ${ }^{246} 9$. Februarii.

Martinus filius Jacobi Klein in Kozliczki a quo aula et mansio empta pro nobis 10. Februarii.

Martinus filius Calvinista 18. Martii.

Catharina puella ex Praboth ${ }^{247}$ eadem die ${ }^{248}$.

Elisabeth puella 14. April[is].

Regina 16. April[is].

Elisabeth puella 17. April[is].

David filius Lutheranae 2.0 April[is].

w 1642 roku przez biskupa chełmińskiego Kaspra Działyńskiego. W Kościeleczkach znajdowała się stała misja rezydencji malborskiej.

241 Obecnie Malbork-Kałdowo, w XVII wieku folwark zamkowy Kołdow, Kołdów - zob. Źródła do dziejów ekonomii malborskiej, t. 4, s. 74.

242 Z miasteczka Nowego Stawu.

243 Nowa Wieś Malborska.

244 Żona rybaka.

245 Właść. niem. Palschau. Wieś Palczewo w województwie pomorskim, w powiecie nowodworskim, w gminie Ostaszewo na obszarze Żuław Wiślanych nad Wisłą.

246 Żona katolika.

247 Prabuty.

24818 marca. 
Martinus famulus ex Villenberg ${ }^{249} 28$. April[is].

Catharina apostata 26. April[is].

Martinus puer 27. April[is].

Anna ex Caldaw ${ }^{250}$ uxor Catholici 2. Junii.

Dorothea Lutherana 2. Junii.

Martinus Mendicus ${ }^{251}$ 4. Junii.

Catharina Ancilla 7. Julii.

Georgius Lignifaber ${ }^{252}$ cum Uxore et 7 prolibus ${ }^{253} 30$. Julii.

Michael Cocus Subditus M[agnificus] D[ominus] Las. ${ }^{254} 10$. Augustii.

Joannes filius Danae conversae 14. Aprilis.

Anna Virgo Sponsa Alberti Sutoris 23. April[is].

Ancilla Anna Gedano oriunda ${ }^{255}$.

Maria Regimonto oriunda Nobilis Joannis Neurath Cap[itanus] Vidua

2. Sept[embris].

Petrus et Catharina ex Ducatu. 8. Sept[embris].

Elisabeth Vidua nutrix ${ }^{256} 22$. Sept[embris].

Regina Puella 27. Sept[embris].

Joannes filius textoris Luth[erani] qui fuit apostata. 6. Octob[ris].

Joannem quendam adolescentem Pucensem ${ }^{257}$ natione a Lutheranismo absolvimus 16. Novembris.

Christophorum Vendit[or] ${ }^{258}$, Lutheranum 24. Novemb[ris].

Joannem Lutheranum 8. Decemb.

Dominam Catharinam Leütnamsche ${ }^{259}$ Lutheranam. 30. Decemb.

Andream Lutheranum 31 Decembris.

249 Malbork-Wielbark.

250 Malbork-Kałdowo.

251 Żebrak, bezdomny, biedak.

252 Cieśla, stolarz, kołodziej.

$253 \mathrm{Z}$ żoną i 7 potomstwa.

254 MD = Magnificus Dominus - Wielmożny Pan. Kucharz, poddany Wielmożnego Pana Las.(?)

255 Pochodząca z Gdańska.

256 Wdowa Elżbieta, mamka.

257 Niejaki Jan pochodzący z Pucka.

258 Kupiec.

259 Porucznikowa, żona porucznika. 


\section{Anno D[omi]ni 1676.}

$\mathrm{Ab}$ haeresi absolutus Paulus Arendatarius noster Neuteychensis ${ }^{260}$.

Item Gertrudem quandam ancillam 1. Januarii.

Estheram Achuppensawer Virginem Mariaeburgensis.

Maria Pomerana 17. Januar[ii] conversa.

Petrus Lang Sculteti 15. Februarii.

Anna Ancilla 6. April[is].

Catharina Mroszowska Vidua ab oppido Brodnica ${ }^{261}$ 19. Apr[ilis].

Albertus infirmus Schismaticus ex Ducali Prussia ${ }^{262} 25$. Aprilis.

Maria Donowska Vidua Regiomonto 263 oriunda 9. Maii.

Matthias.

Item Maria quaedam Vaga[bunda] ${ }^{264}$ 26. Maii.

Michael et Joannes 31. Maii.

Andreas a Schismate.

Agnes ab Apostasia 4. Junii.

Anna infirma puella ex Lauenburgensi districtu ${ }^{265} 19$. Junii.

Joannes Reuth Danus ${ }^{266}$ 2. Julii.

Christina Elbingo oriunda ${ }^{267}$ 12. Julii.

Absolutus ab Haeresi 2. Sept[embris] Jacobus infirmus qui fuit in obsequiis M[agnifici] D[omini] Oeconomi ${ }^{268}$ de Belli.

Item infirmus Andreas Bąk operarius ${ }^{269} 3$. Septemb[ris].

Joannes Braxator arcensis 270 20. Novembris qui mox obiit.

260 Paweł, arendarz jezuitów malborskich w Nowym Stawie.

261 Brodnica (niem. Strasburg) - miasto w województwie kujawsko-pomorskim, siedziba powiatu brodnickiego, w XVII wieku starostwo grodowe.

262 Prawosławny z Prus Książęcych - prawdopodobnie z emigracji z lat 1654-1656.

263 Wdowa pochodząca z Królewca. Królewiec (niem. Königsberg, ros. Kaliningrad) - ówcześnie stolica Prus Książęcych.

264 Vagabunda - włóczęga.

$265 \mathrm{Z}$ powiatu lęborskiego (lenna brandenburskiego). Lębork (niem. Lauenburg) - miasto w województwie pomorskim, siedziba powiatu lęborskiego.

266 Duńczyk.

267 Pochodząca z Elbląga. Elbląg (niem. Elbing) - miasto w województwie warmińsko-mazurskim, siedziba władz powiatu elbląskiego i gminy wiejskiej Elbląg.

268 Sługa ekonoma malborskiego Franciszka Jana Bielińskiego z czasów wojny.

269 Wyrobnik (pracownik najemny, najemnik).

270 Piwowar zamkowy, który wkrótce zmarł. 


\section{Anno D[omi]ni 1677.}

Christina ancilla ex Cyngara ${ }^{271}$ facta Lutherana demum Catholica 1. Januar[ii].

Item Anna ex Suburbio.

Ancilla Catharina oriunda Christiburgo ${ }^{272}$ 18. Jan[uarii].

Samuel textor ${ }^{273}$ Lithuanus $^{274}$ 27. Jan[uarii].

Joannes Sartor ${ }^{275}$ Brądewaldensis. 29. Jan[uarii].

Quaedam ex Suburbio Lutherana 13. Martii.

Puella Catharina ex Suburbio 11. April[is].

Judith quaedam Apostata 15. April[is].

Quaedam absoluta Lutheranismo 22. Apr[ilis].

Christianus famulus noster ${ }^{276}$ in Kozliczk[i]. 7. Junii.

Domina Chodzewska 8. Sept[embris].

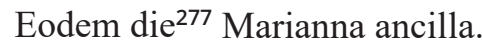

Andreas ex Ducatu Lutheranus 29. Sept[embris].

Eodem die ${ }^{278}$ revocavit Petrus Panser Nagel, in vallo arcensi manens qui primus suit et Vidit candelas ardentes noctuante imaginem B[eatissi]mae extra templum versus vallem ${ }^{279}$, pluresq[ue] convocauerat ad conspiciendum, posteaq[ue] aliis ex hoc motivo conversis, ipse in ludibrium et risum omnia convertit, dixitq[ue] malle se quavis morte ignominiose perire, quam fidem Catholicam profiteri, Sed tandem victus Deo se dedit.

271 Zapewne Cygany (niem. Ziegahnen) - obecnie część wsi Mątowy Małe w województwie pomorskim, w powiecie malborskim, w gminie Miłoradz lub Cyganek (niem. Tiegenhagen) osada w województwie pomorskim, w powiecie nowodworskim, w gminie Nowy Dwór Gdański na obszarze Żuław Wiślanych.

272 Pochodząca z Dzierzgonia.

273 Tkacz.

274 Czyli obywatel Wielkiego Księstwa Litewskiego.

275 Gościszewo (dawn. Brądwałd, Brądewałd, niem. Braunswalde) - wieś w województwie pomorskim, w powiecie sztumskim, w gminie Sztum.

276 Parobek jezuitów malborskich z Kościeleczek.

2778 września.

27829 września.

279 Monumentalna figura Matki Boskiej Malborskiej z Dzieciątkiem ulokowana w niszy zewnętrznej od strony wschodniej kościoła zamkowego Najświętszej Marii Panny w Malborku. 


\section{Anno D[omi]ni 1678.}

Mulier Catharina ex Kominki ${ }^{280}$ 8. Febr[uarii].

Barbara 8 annoru[m] apostata 12. Mar[tii].

Joannes Hempel arcularius ${ }^{281} 15$. Martii.

Henricus Maier Gedanen[si] 10. April[is].

Eodem die ${ }^{282}$ Joannes ex Pomerania Servus Domini Hertman.

Marianna ex Suburbio maritata qua fuerat apostata annis 6. 12. April[is].

Item Elisabetha ex Suburbio maritata.

Quidam famulus ab Haeresi absolutus 1. Maii.

Virgo Rosina Lang ex Weiersdorff ${ }^{283}$. 19. Maii.

Paulus Subditus M[agnificus] D[ominus] Zawacki ${ }^{284}$ in Greimala ${ }^{285}$ cum

filia absolutus ab haeresi Lutherana, 9. Junii.

Eodem die ${ }^{286}$ Jacobus educendus ad Supplicium.

Catharina quaedam 4. Julii.

Eva a fide Catholica apostata rediit 11. Sept[embris].

Christophorus miles 24. Sept[embris].

Petrus adolescens a fide Catholica apostata absolutus 18. Decemb[ris].

Uxor cuiusdam Regimontani Lutherani conversa et absoluta 19.

Decemb[ris].

Ursula Lutherana conversa et absoluta.

\section{Anno D[omi]ni 1679.}

Elias Lutheranus 4. Januarii.

Filia eiusdem Patrem secuta 21. Febr[uarii].

280 Kamionka (folwark zamkowy Kominki).

281 Cieśla, stolarz.

28210 kwietnia.

283 Zapewne Wernersdorf. Obecnie Pogorzała Wieś w województwie pomorskim, w powiecie malborskim, w gminie Miłoradz, nad Nogatem na obszarze Wielkich Żuław Malborskich.

284 Poddany Samuela Zawadzkiego h. Ostoja, wójta i burgrabiego malborskiego - zob. J. N. Bobrowicz, Herbarz polski Kaspra Niesieckiego, t. 10, Lipsk 1845, s. 102. Ten ostatni sprzedał jezuitom malborskim majątek Grzymała (ówcześnie Grzymały) w 1681 roku - AAWO, H. 11, Historia Residentiae Mariaburgensis, k. 24.

285 Zapewne zniekształcona nazwa majątku Grzymała, w oryginale kroniki rezydencji malborskiej Grzymali. Obecnie Grzymała - przysiółek wsi Dąbrówka Malborska w województwie pomorskim, w powiecie sztumskim, w gminie Stary Targ.

2869 czerwca. 
Catharina famula M[agnifici] D[omini] Burgrabii ${ }^{287}$ 11. Martii.

Nobilis quaedam conversa 24. Martii

Gregorius Calvinista 9. Aprilis.

Joannes Gaspar miles 11. Maii.

Uxor cuiusdam ex Suburbio Lutherana 23. Maii.

Barbara 4. Junii.

Quaedam Lutherana ex Saxonia ${ }^{288}$ 19. Junii.

Catharina puella qua in infirmitate promisit se fore catholicam si convalesceret et convaluit. 8. Jul[ii].

Item Regina absoluta ab haeresi 24. Martii.

Et Barbara 4. Junii.

\section{Bibliografia}

\section{Źródła archiwalne}

Archiwum Archidiecezji Warmińskiej w Olsztynie, sygn. H. 11, Historia Residentiae Mariaburgensis Ab Anno 1647.

Archiwum Diecezjalne w Pelplinie, C. 23, k. 55-61v.

Archiwum Główne Akt Dawnych, Metryka Koronna, Kontrakt o Malborską Ekonomię 1660, Lustracje, dz. XVIII, sygn. 78.

\section{Archivum Romanum Societatis Iesu:}

Pol. 61, Annuae Poloniae 1685-1710.

Pol. 52, Annuae Provinciae Poloniae 1638, 1642, 1643, 1644.

Pol. 53, Annuae Provinciae Poloniae, 1660, 1661, 1662, 1663, 1664, 1665, 1666, 1669.

Pol. 54, Annuae Provinciae Poloniae 1670, 1671, 1672, 1673, 1675, 1676.

Pol. 55, Annuae Provinciae Poloniae 1678, 1679.

Pol. 43, Catalogus Brevis Provinciae Poloniae 1617/1618,1618/1619,1619/1620,

Pol. 44, Catalogus Brevis Provinciae Poloniae 1654/1655, 1660/1661, 1661/1662, 1663/1664, $1664 / 1665,1665 / 1666,1666 / 1667,1667 / 1668,1672 / 1673,1674 / 1675,1675 / 1676,1676 / 1677$, $1678 / 1679,1679 / 1680$

287 Służąca Samuela Zawadzkiego, wspomnianego powyżej burgrabiego malborskiego - zob. Źródła do dziejów ekonomii malborskiej, t. 4, dz. cyt., s. 91.

288 Z Saksonii. 
Pol. 13, Cat. Trienn. 1655.

Pol. 14, Cat. Trienn. 1665.

Pol. 15, Cat. Trienn. 1669, 1672.

Pol. 16, Catalogus Triennalis 1675.

Pol. 17, Catalogus Triennalis 1678.

Pol. 53, Historiae Poloniae 1648-1671, Series eorum Qui Societatis Jesu opera ab Anno Salutis 1662 ad 1678, Fidem Catholicam sunt amplexi in Polonia, Mariaeburgensis Residentia, k. 252-268v.

Pol. 55, Historia Triennalis Residentiae Mariaeburgensis Societatis Jesu Annus 1683.

\section{Źródła drukowane}

Dzieje malborskiej rezydencji Towarzystwa Jezusowego 1647-1744. Z rękopisu H 11 Archiwum Archidiecezji Warmińskiej w Olsztynie przełożył biskup Julian Wojtkowski, Olsztyn 2013.

Konstytucje Towarzystwa Jezusowego wraz z przypisami Kongregacji Generalnej XXXIV oraz normy uzupetniajace zatwierdzone przez tę sama Kongregację, Kraków-Warszawa 2001. Reguly Societatis Iesu, Sandomierz 1696.

Wilhelmi S., Collectanea. Marienburg in schwerer Zeit: Aufzeichnungen eines preussischen Bürgermeisters zwischen 1696 und 1726, wyd. R. Zacharias, Frankfurt am Main 2006. Źródła do dziejów ekonomii malborskiej, t. 4, Akta malborskiej komisyjej za konstytucyja roku 1661 odprawionej i na dalszy czas odłożonej, wyd. W. Hejnosz, J. Waluszewska, Toruń 1967.

\section{Opracowania}

Augusiewicz S., Spis uchodźców z Wielkiego Księstwa Litewskiego w Prusach Książęcych w latach 1655-1656 w zbiorach Geheimes Staatsarchiv Preussicher Kulturbesitz w Berlinie, „Komunikaty Mazursko-Warmińskie” t. 1 (2011), s. 97-181.

Bobrowicz J.N., Herbarz polski Kaspra Niesieckiego, t. 2, Lipsk 1839; t. 7, Lipsk 1841; t. 10, Lipsk 1845.

Długokęcki W., Kaplica i wikaria Najświętszej Marii Panny na Bramie Przewozowej w Malborku w średniowieczu, w: Mieszczanie, wasale, zakonnicy, red. B. Śliwiński, Gdańsk 2004, s. 61-73 (Studia z Dziejów Średniowiecza, 10).

Drzymała K., Praca jezuitów nad ludnością wiejską w pierwszym stuleciu osiedlenia się zakonu w Rzeczypospolitej, „Nasza Przeszłość” t. 20 (1964), s. 51-75.

Encyklopedia wiedzy o jezuitach na ziemiach Polski i Litwy 1564-1995, oprac. L. Grzebień SJ przy współpracy zespołu jezuitów, wyd. 2, Kraków 2004.

Hartknoch Ch., Preussische Kirchen-Historia, Danzig 1686.

Józefczyk M., Z dziejów religijnych Pomezanii w XVII wieku, t. 1-2, Malbork 2012.

Kołacz J., Stownik języka i kultury jezuitów polskich, Kraków 2006. 
Kościelak S., Dzieje wyznaniowe Prus Królewskich w XVI-XVIII w., w: Prusy Królewskiespołeczeństwo, kultura, gospodarka 1454 - 1772. Szkice z dziejów, red. E. Kizik, Gdańsk 2012, s. 204-263.

Kościelak S., Jezuici w Gdańsku od drugiej połowy XVI do końca XVIII wieku, GdańskKraków 2003.

Kościelak S., Jezuici w trzech wielkich miastach pruskich w XVI-XVIII w., „Hereditas Monasteriorum" t. 3 (2013), s. 155-187.

Kościelak S., Konwertyci elbląscy w świetle jezuickiego Fructus missionis z XVIII wieku, „Rocznik Elbląski”, t. 20 (2006), s. 183-192.

Kościelak S., Skład osobowy kolegium gdańskiego oo. jezuitów (XVI-XVIII wiek), Gdańsk 2005, s. 168-174.

Labuda A. S., Zaginione, nieodnalezione. O obrazie Matki Boskiej Pokornej z Malborka oraz o predelli ołtarza św. św. Piotra i Pawia z kościoła Mariackiego w Gdańsku, w: Żeby wiedzieć. Studia dedykowane Helenie Makiewiczównie, red. W.Walanus, Kraków 2008, s. 81-98.

Łukaszewska-Haberkowa J., Wpływ pierwszego pokolenia polskich jezuitów na życie kulturalne i religijne Rzeczypospolitej Obojga Narodów w latach 1564-1608, Kraków 2014.

Łuszczak G., Nauczyciele i wychowawcy szkół jezuickich we Lwowie 1608-1773, Kraków 2010.

Mariani A., Duszpasterstwo jezuitów nieświeskich w XVII-XVIII wieku. Między ideałem potrydenckim a lokalnymi uwarunkowaniami, ,Rocznik Lituanistyczny” 2 (2016), s. 4791.

Młodzianowski T., Kazania i homilyie na niedziele doroczne, Poznań 1681.

Panfil R., Kontrakt na ekonomię malborska z 1663 r., w: W stużbie zabytków. Księga Pamiatkowa ofiarowana Mariuszowi Mierzwińskiemu w 40-lecie pracy muzealnej w Malborku, red. J. Hochleitner, K. Polejowski, Malbork 2017, s. 161-171.

Panfil R., Pierwsi jezuici w Malborku jako reprezentanci multietnicznego społeczeństwa Rzeczpospolitej Obojga Narodów, w: Stan badań nad wielokulturowym dziedzictwem dawnej Rzeczypospolitej, red. W. Walczak, K. Łopatecki, Białystok 2017, s. 243-295.

Panfil R., Starania Stanisława Kuklińskiego o przejęcie kościoła zamkowego w Malborku, „Echa Przeszłości” nr 18 (2017), s. 171-198.

Panfil R., Stosunki religijne w Malborku od początku reformacji do początku XVII w., „Studia Zamkowe" 5 (2018) s. 93-108.

Sahanowicz H., Wychodźcy z Wielkiego Księstwa Litewskiego w Prusach 1656 roku, „LituanoSlavica Posnaniensia, Studia Historica" 9 (2003), s. 239-245.

Trzy wieki w granicach Rzeczpospolitej. Zamek malborski od inkorporacji do rozbioru (1454-1772). Katalog wystawy, opr. A. Dobry, Malbork 2014.

Walczak B., Maty słownik etymologiczno-historyczny kacerstwa polskiego, „Poznańskie Studia Polonistyczne, Seria Literacka" 3 (1996), s. 11-29. 
Wiślicz T., ,,Jak gdyby wśród pogan lub heretyków”. Polityka potrydenckiego Kościoła wobec religii ludowej i jej osobliwości w Rzeczypospolitej, w: Staropolski ogląd świata. Rzeczypospolita między okcydentalizmem a orientalizacją. Przestrzeń wyobrażeń, red. R. Kołodziej, F. Wolański, Torun 2009, t. 2, s. 31-42.

Wiślicz T., Pedagogika strachu w Kościele potrydenckim $w$ Polsce, w: Sic erat in fatis. Studia i szkice historyczne dedykowane Profesorowi Bogdanowi Rokowi, red. E. Kościk, R. Żerelik, P. Badyna, F. Wolański, Torun 2012, t. 1, s. 283-298.

Wojtkowski J., Konwertyci w kronice jezuitów malborskich 1647-1744, w: Jezuici w Malborku a życie religijne na terytorium diecezji pomezańskiej $w$ okresie nowożytnym, red. J. Hochleitner, Malbork 2014, s. 121-132.

Zawadzki W., Duchowieństwo katolickie oficjałatu pomezańskiego w latach 1525-1821, t. 1-2, Elbląg 2009.

Zawadzki W., Zakony w Pomezanii w XVII-XIX w., Olsztyn-Elbląg 2013. 